\title{
The 3D interplay between folding and faulting in a syn-orogenic extensional system: the Simplon Fault Zone in the Central Alps (Switzerland and Italy)
}

\author{
Marion Campani · Neil Mancktelow • \\ Gabriel Courrioux
}

Received: 9 October 2013/Accepted: 7 July 2014/Published online: 23 August 2014

(C) Swiss Geological Society 2014

\begin{abstract}
Extensional low-angle detachments developed in convergent or post-collisional settings are often associated with upright folding of the exhumed footwall. The Simplon Fault Zone (SFZ) is a Miocene low-angle detachment that developed during convergence in the Central Alps (Switzerland and Italy), accommodating a large component of orogen-parallel extension. Its footwall shows complex structural relationships between large-scale backfolds, mylonites and a discrete brittle detachment and forms a 3D gneiss dome reflecting upright folding with fold axes oriented both parallel and perpendicular to the extension direction. We present a regional study that investigates the interplay between folding and faulting and its implications for the resulting exhumation pattern of the gneiss dome using 3D geometric modelling (computer software GeoModeller), together with a consideration of the chronological relationships from field relationships and ${ }^{40} \mathrm{Ar} /{ }^{39} \mathrm{Ar}$ dating. The early Simplon mylonitic fabric is clearly folded by both extension-parallel and extension-
\end{abstract}

Editorial handling: A. G. Milnes.

Electronic supplementary material The online version of this article (doi:10.1007/s00015-014-0163-y) contains supplementary material, which is available to authorized users.

M. Campani - N. Mancktelow

Departement Erdwissenschaften, ETH Zürich, 8092 Zurich,

Switzerland

G. Courrioux

BRGM, B.P. 6009, 45060 Orléans Cedex, France

Present Address:

M. Campani $(\bowtie)$

Biodiversity and Climate Research Centre (BiK-F),

Senkenberganlage 25, 60325 Frankfurt, Germany

e-mail: mcampani82@gmail.com perpendicular folds, forming a doubly plunging antiform, whereas the later ductile-to-brittle fabric and the cataclastic detachment are only affected by wavy extension-parallel folds. This observation, together with the interpreted cooling pattern across the SFZ, suggests that updoming of the footwall initiated at the onset of faulting during ductile shearing around $18.5 \mathrm{Ma}$, due to coeval extension and perpendicular convergence. New ${ }^{40} \mathrm{Ar} /{ }^{39} \mathrm{Ar}$ dating on micas (biotite and muscovite) from a sample affected by a strong crenulation cleavage parallel to the axial plane of the Glishorn and Berisal parasitic folds establishes that these folds formed at ca. $10 \mathrm{Ma}$, broadly coeval with late movement along the more discrete detachment of the SFZ. These extension-parallel folds in the footwall of the SFZ developed due to continued convergence across the Alps, accelerating ongoing exhumation of the western Lepontine dome and promoting coeval uplift of the crystalline Aar and Gotthard massifs in the late Miocene.

Keywords Folding - Low-angle detachment . Exhumation $\cdot$ Geometric modelling

\section{Introduction}

An interplay between large-scale upright folding and lowangle faulting is typical of many extensional detachment systems world-wide (e.g. Yin 1991; Chauvet and Séranne 1994; Mancktelow and Pavlis 1994; Avigad et al. 2001; Martinez-Martinez et al. 2002). In such structures, generally two sets of folds are described, with fold axes parallel and perpendicular to the regional extension direction. These folds control the 3D geometry of exhumation of the footwall, leading to elongated domal forms (Spencer 2010), which were originally described as "turtlebacks" 
(e.g. Drewes 1959) or "metamorphic core complexes" (e.g. Wernicke 1981; Lister 1984). Both sets of footwall folds are considered to develop synchronously with extension, based on structural relationships and relative chronology. They are attributed either to one single or two distinct mechanical events. Possible single processes that have been proposed include emplacement of syn-extensional plutons or updoming above undulating crustal roots (Yin 1991). In models proposing two distinct processes, the formation of extension-orthogonal folds is most commonly attributed to isostatic unloading in a rolling hinge system (e.g. Spencer 1984, 1985; Buck 1988; Wernicke and Axen 1988) while extension-parallel folds are often considered as primary fault corrugations developed during fault slip (e.g. John 1987; Spencer 2010). However, numerous other studies have argued that these extension-parallel folds are contractional features reflecting synchronous horizontal compression perpendicular to the extension direction (e.g. Spencer 1985; Bartley et al. 1990; Yin 1991; Chauvet and Séranne 1994; Mancktelow and Pavlis 1994; Avigad et al. 2001; Martinez-Martinez et al. 2002).

Here, we characterise the 3D interplay between upright folding and extensional faulting within a low-angle detachment system that developed in a convergent and thick orogen: the Simplon Fault Zone (Mancktelow 1985, 1990; Mancel and Merle 1987; Steck and Hunziker 1994) located in the Central Alps (Switzerland and Italy; Fig. 1). This fault zone shows a complex overprint of extensionparallel folds affecting both the discrete detachment and the ductilely deformed rocks of the footwall. This pattern has been interpreted in the Alps as due to perpendicular shortening, either coeval with orogen-parallel extension (Mancktelow 1992; Mancktelow and Pavlis 1994) or separating two distinct extensional stages (Steck and Hunziker 1994). We first present a review of the structural relationships between shearing and folding, and of the chronology of these deformations. Results of new ${ }^{40} \mathrm{Ar} /{ }^{39} \mathrm{Ar}$ dating of two mica separates from one sample are presented with the aim of directly dating the development of the extension-parallel folds. Many studies in the Central Alps highlight the necessity of using a 3D approach to represent such complexly deformed regions, either using 2.5D block diagrams (e.g. Steck 1984, 2008; Mancktelow 1985; Steck and Hunziker 1994) or full 3D geometric models (Maxelon 2004; Maxelon and Mancktelow 2005; Maxelon et al. 2009). We model the 3D interplay between extensional faulting and folding that led to exhumation in the Central Alps using the commercial GeoModeller software package, which is based on the potential field method (Lajaunie et al. 1997; Aug et al. 2005), employing a similar approach to that developed by Maxelon (2004), Maxelon and Mancktelow (2005) and Maxelon et al. (2009) in the Lepontine Alps. Finally, the initiation and evolution of extension-parallel and extension-perpendicular folds is discussed, based on the 3D structural relationships, together with the new direct ${ }^{40} \mathrm{Ar} /{ }^{39} \mathrm{Ar}$ dating, and an interpretation of the cooling pattern across the fault zone already established in earlier publications (Campani et al. 2010a, b).

\section{Structural and chronological setting of the Simplon region}

\subsection{Coupling between folding and extensional faulting}

\subsubsection{D geometry of the low-angle detachment system}

The SFZ is an extensional low-angle detachment system in the Central Alps that resulted in exhumation of the western part of the Lepontine metamorphic dome (Fig. 1). As a result, the immediate footwall of the SFZ represents a ductile shear zone showing a transition from a broader zone of older, warmer mylonites (initially amphibolite facies in regions I, II, III, Fig. 1b) to a narrower zone of younger, colder mylonites (greenschist facies), with subsequent brittle overprint partly localised on a discrete normal detachment (the "Simplon Line") (e.g. Steck 1984, 1990, 2008; Mancktelow 1985, 1990, 1992; Mancel and Merle 1987; Mancktelow and Pavlis 1994; Campani et al. 2010a, b; Haertel et al. 2013; Steck et al. 2013). Clear kinematic indicators give a consistent normal or top-to-SW sense of shear (Fig. 2a), associated with a generally well-developed stretching lineation that is consistently oriented NE-SW over the entire fault zone (Figs. 1a, 2b). It is still controversial whether the change from the broader zone of older, warmer mylonites to the narrower zone of younger, colder mylonites and brittle faulting was a relatively distinct twostage process (Oligocene and Miocene to Recent, respectively; Steck 1984, 1990, 2008; Steck and Hunziker 1994; Steck et al. 2013) or instead reflects a single period of progressive footwall exhumation starting in the mid-Miocene (Mancktelow 1985, 1990, 1992; Grasemann and Mancktelow 1993; Mancktelow and Pavlis 1994; Campani et al. 2010a, b).

A compilation of foliation measurements along the fault zone is published in Campani et al. (2010b). In the central region (region I, Fig. 1b), the brittle detachment dips at a low angle of $25-30^{\circ}$ toward the SW and the older ductile mylonitic foliation (referred to here as Sm; Mancktelow 1985, 1990, 1992; Campani et al. 2010b) within the immediate footwall is sub-parallel, with a slightly lower average dip of $22^{\circ}$. In the southern area (region II, Fig. 1b), Sm and the brittle detachment both dip steeply to the SSE $\left(62^{\circ}\right.$ toward $\left.155^{\circ}\right)$ within the so-called "Southern Steep Belt" described by Milnes (1974). In this region, the 


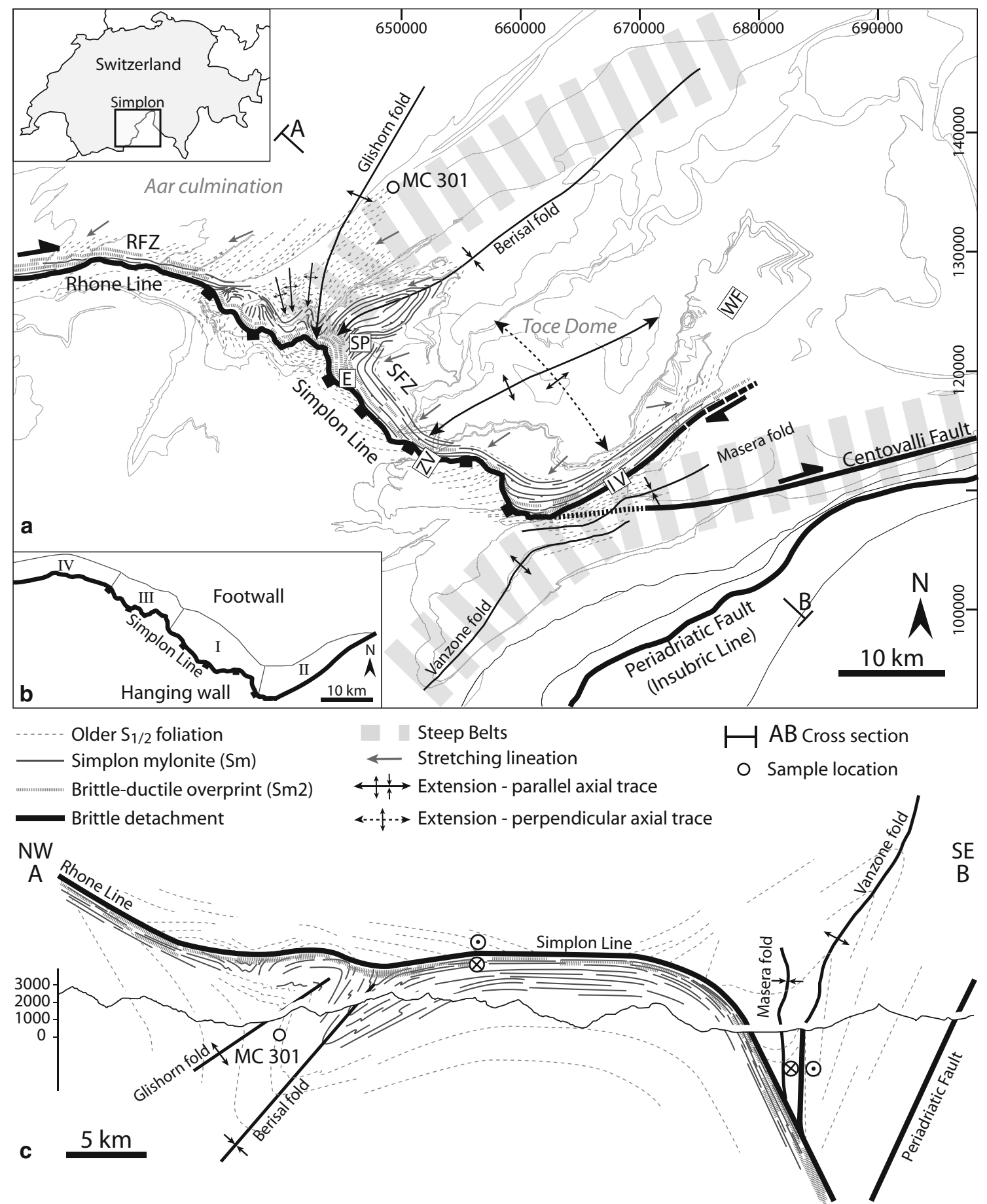

Fig. 1 Structural setting of the SFZ a Structural map of the Simplon Fault Zone (SFZ) in the Simplon region of the Central Alps (see inset for location). b Subdivision into geographical regions I to IV. c NWSE cross-section perpendicular to the extension direction. $R F Z$ Rhone

overall displacement corresponds to a dextral strike-slip fault zone (Fig. 1a). The northern region (region III, Fig. 1b) presents a more complex 3D geometry. The main mylonitic foliation Sm and brittle detachment are no longer parallel (Fig. 1a). Sm is folded around the Berisal synform
Fault Zone, SFZ Simplon Fault Zone; SP Simplon Pass location; $E$ Engiloch location, $Z$ Zwischbergen Valley, $I V$ Isorno Valley, $W F$ D2 Wandfluhorn fold

and Glishorn antiform within the "Northern Steep Belt" (Milnes 1974), with the fold axes parallel to the regional extension direction (Steck 1984; Mancel and Merle 1987; Mancktelow 1990, 1992; Mancktelow and Pavlis 1994). The folded Sm foliation is transected by a narrower band of 

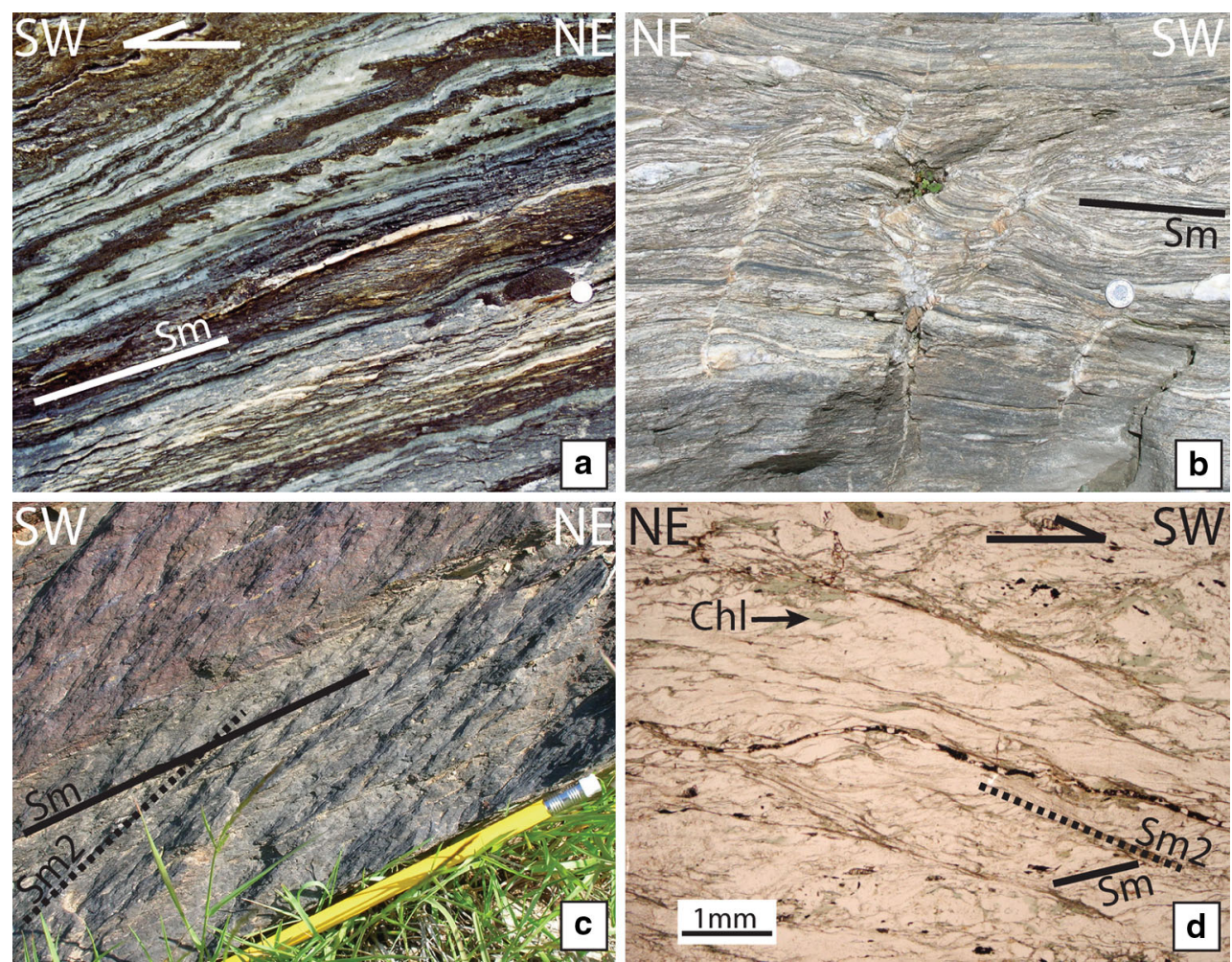

Fig. 2 Extensional low-angle detachment system. a Older high grade Simplon mylonites $(\mathrm{Sm})$ in Mesozoic calcschists and marbles, with top-to-SW shear sense, Sion-Courmayeur Zone, footwall (645001/ 119513). b Foliation boudinage of the old (Sm) Simplon mylonites showing the strong NE-SW stretching component, calcareous meta-

pelite, Monte Leone unit, footwall (646076/127006). c Discordant greenschist facies mylonitic foliation Sm2, psammite, Berisal Unit, footwall (644933/121830). d Greenschist facies mylonitic foliation Sm2 close to the brittle detachment, micaschist, Berisal Unit, footwall (643705/121897). Chl chlorite

greenschist facies mylonites (Mancktelow 1990, 1992) with a foliation, referred to here as Sm2 (Campani et al. 2010b). Sm2 is concordant with the Simplon brittle detachment (Fig. 2c), strongly developed close to the detachment itself, and also overprinted by broad-scale, open, wavy folds, with axes parallel to the regional extension direction (Mancktelow 1992; Mancktelow and Pavlis 1994). Both the older, folded (Sm) and younger, transecting (Sm2) mylonitic fabrics developed under retrograde metamorphic conditions, but the younger mylonites are comparatively chlorite-rich, developed more discrete shear planes (Fig. 2d), and were locally brecciated. They formed at lower grade, close to the ductile-to-brittle transition (Mancktelow 1990, 1992; Axen et al. 2001). Both mylonites show identical kinematics (Mancktelow 1992; Steck and Hunziker 1994). In the Rhone Valley (region IV, Fig. 1b), the older ( $\mathrm{Sm}$ ) mylonites and brittle detachment are again effectively parallel and show a change in strike, with the fault zone oriented approximately E-W (on average dipping $35^{\circ}$ toward $184^{\circ}$; Fig. 1a). As a result, the displacement along the Rhone Valley is dominantly dextral strike-slip with a slight normal component,

with the stretching lineation consistently pitching ca. $20^{\circ}$ SW within the foliation plane.

\subsubsection{Extension-orthogonal folding}

Within the footwall, the dip of Sm flattens with increasing distance from the detachment and this broad-scale fold with axis perpendicular to the regional extension direction (e.g. Mancktelow 1990; Steck and Hunziker 1994) produces, in combination with the extension-parallel folds considered below, an overall domal shape, the so-called Tosa (or Toce) Culmination or Dome (Fig. 1a; Preiswerk 1921; Wenk 1955; Steck and Hunziker 1994). The domal shape is reflected in the southeast (regions II, Fig. 1b) by opposite plunge directions (toward SW and toward NE) of the stretching lineation within the foliation plane (Mancktelow 1985). This domal shape in the older ductile mylonites is not seen in the structures formed during the later brittle history of region II (Fig. 1b), where the brittle striation is always nearly horizontal (Campani et al. 2010b). The implication is that the regional up-doming had effectively ceased, or significantly diminished, prior to this late, brittle, and more discrete overprint. 

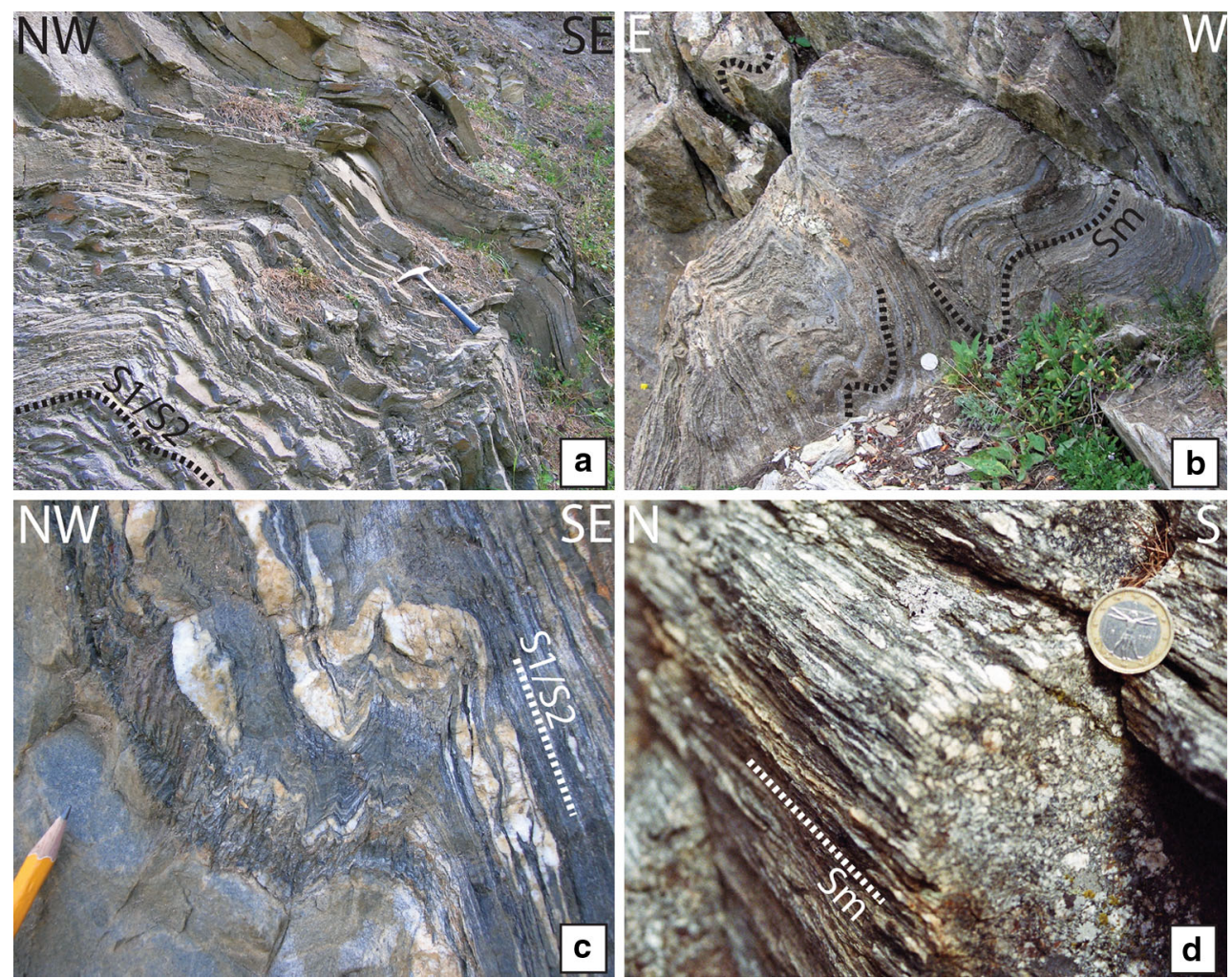

Fig. 3 Extension-parallel folds in the Northern Steep Belt $\left(D_{4}\right.$ backfolds). $\mathrm{D}_{4}$ open parasitic folds folding the pre-existent regional $\mathrm{S}_{1} / \mathrm{S}_{2}$ fabric (a) and the older Simplon mylonitic foliation $\mathrm{Sm}$ (b); calcschist, Sion-Courmayeur Zone, footwall (641204/ 127695-643759/121857). c $S_{4}$ crenulation cleavage development

associated with the D4 backfolds, calcschist, Sion-Courmayeur Zone, footwall (646136/130530). d Linear constrictional fabric developed in the older high grade Simplon mylonites, augen orthogneiss, Berisal Unit, footwall (644742/119344)

\subsubsection{Extension-parallel folding or backfolding}

In regional syntheses of deformation in the Central Alps, extension-parallel folds or backfolds are described as "SE-vergent backfold" structures (e.g. Milnes et al. 1981; Maxelon and Mancktelow 2005). In the relative age scheme used here, we refer to them as the D4 deformation phase. The wavy to open folds (Fig. 3a, b) are generally upright to moderately overturned to the SE, with a new axial planar cleavage only locally developed (Fig. 3c). They are essentially restricted to the Northern Steep Belts (Glishorn and Berisal folds) and Southern Steep Belts (Vanzone and Masera folds; Fig. 1a, c) and, in the case of the Glishorn, Berisal and Masera structures, developed under retrograde metamorphic conditions (Milnes et al. 1981; Steck 2008; Steck et al. 2013). In the footwall of the fault zone, the interference between these extension-parallel folds and the SW shearing locally developed a finite constrictional strain with a predominantly linear fabric (Fig. 3d). Measured orientations of the backfold hinges and axial planes are summarized in Fig. 4. In the Northern Steep Belt, the backfolds trend SW-NE, with the mean orientation of

fold axes plunging shallowly at $12^{\circ}$ toward $234^{\circ}$ (Fig. 4a, b). This orientation is effectively parallel to the stretching lineation, which has a mean orientation plunging $19^{\circ}$ toward $240^{\circ}$ (Fig. 4a). Axial planes are more variable in dip and dip direction (Fig. 4b). In style, these folds are generally open with a rounded hinge geometry (Fig. 3a, b). In the Southern Steep Belt, the Masera synform is an open structure (Fig. 1c) that developed under greenschist facies metamorphic conditions (Milnes et al. 1981; Steck 2008; Steck et al. 2013), with common parasitic folds showing a chevron or kinklike geometry. In contrast, the Vanzone backfold is a tighter antiform that formed under amphibolite facies metamorphic conditions (Steck 2008; Steck et al. 2013). These backfolds in the Southern Steep Belt have steep axial planes striking WSW-ENE and a mean orientation of fold axes plunging shallowly, with an average of $7^{\circ}$ toward $257^{\circ}$ (Fig. 4c, d). Further to the southwest, the axial planes rotate into a SW-NE strike direction (e.g. Steck 2008) as seen in Fig. 1a. Keller et al. (2005) proposed that this strike rotation was in fact characterised by a series of contemporaneous en-echelon anticlines and synclines. 


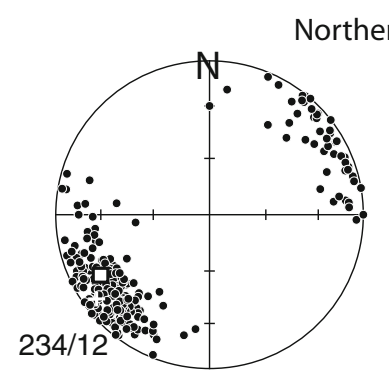

a Fold axis, $\mathrm{n}=240$

a Mean stretching lineation

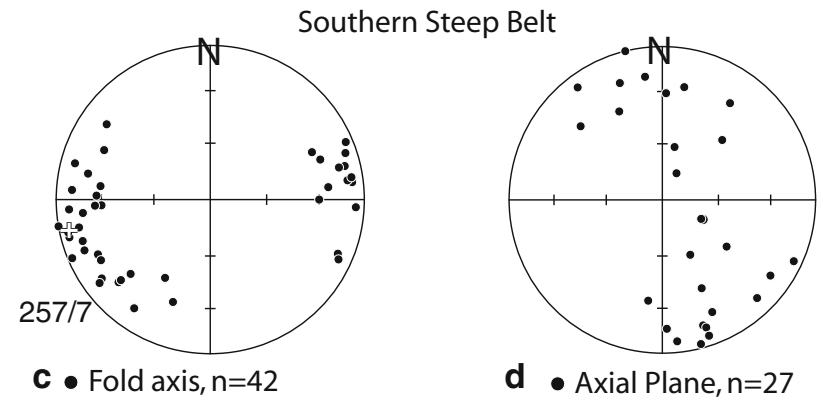

Fig. 4 Field measurements related to $\mathrm{D}_{4}$ backfolds in the Northern $(\mathbf{a}, \mathbf{b})$ and Southern $(\mathbf{c}, \mathbf{d})$ Steep Belts. Lower hemisphere, equal area projection; The mean fold axis orientation is indicated (cross) as well as the mean stretching lineation (240/19) related to the Simplon Fault Zone in the Northern Steep Belt (square)

\subsubsection{The regional Alpine structural history and the SFZ overprint}

The main fabric observed in the Central Alps corresponds to an earlier fabric $S_{1 / 2}$ (Fig. 1) reflecting the combined effect of two major regional deformation phases D1 and D2 (e.g. Milnes et al. 1981; Steck 1984; Grujic and Mancktelow 1996; Maxelon and Mancktelow 2005). The first phase of deformation observed, D1, corresponds to the development of a NW-vergent nappe stack. It develops an intense isoclinal folding on the kilometre scale, associated with the development of an $\mathrm{S}_{1}$ axial plane cleavage (Fig. 5a). D1 is followed by tight to isoclinal post-nappe refolding on a regional scale, D2 (e.g. the Monte Leone and Antigorio "nappe" folds), with the development of an $\mathrm{S}_{2}$ axial plane cleavage (Fig. $5 b, c)$. The D2 fold axes are SW-NE oriented, parallel to the trend of the orogen (e.g. Maxelon and Mancktelow 2005) and associated with prograde metamorphism. A third deformation phase, D3 (e.g. Maxelon and Mancktelow 2005), is also observed but it is only poorly represented in the Simplon region. It causes wavy to open folding of the whole tectonostratigraphy, with axial planes commonly trending NW-SE to N-S, leading to the so-called "cross-folds" (e.g. Steck 1998). This phase develops a weak crenulation lineation, sometimes also associated with a weak crenulation cleavage $S_{3}$
Fig. 5 Deformation structures that pre-date development of the SFZ (D1, D2). a F1 folds refolded by F2 in calcschist, Sion-Courmayeur Zone, footwall (649898/123263). b F1 folds refolded by F2, with development of an $\mathrm{S}_{2}$ axial plane schistosity in calcschist, Sion-Courmayeur Zone, footwall (649384/123073). c $\mathrm{S}_{2}$ crenulation cleavage overprinting the main $\mathrm{S}_{1}$ foliation, psammite, Houillère Zone, hanging-wall (635033/ 122807). d Synthetic sketch of the principal deformation phases observed on an outcrop scale, hanging-wall (635083/ 122450)
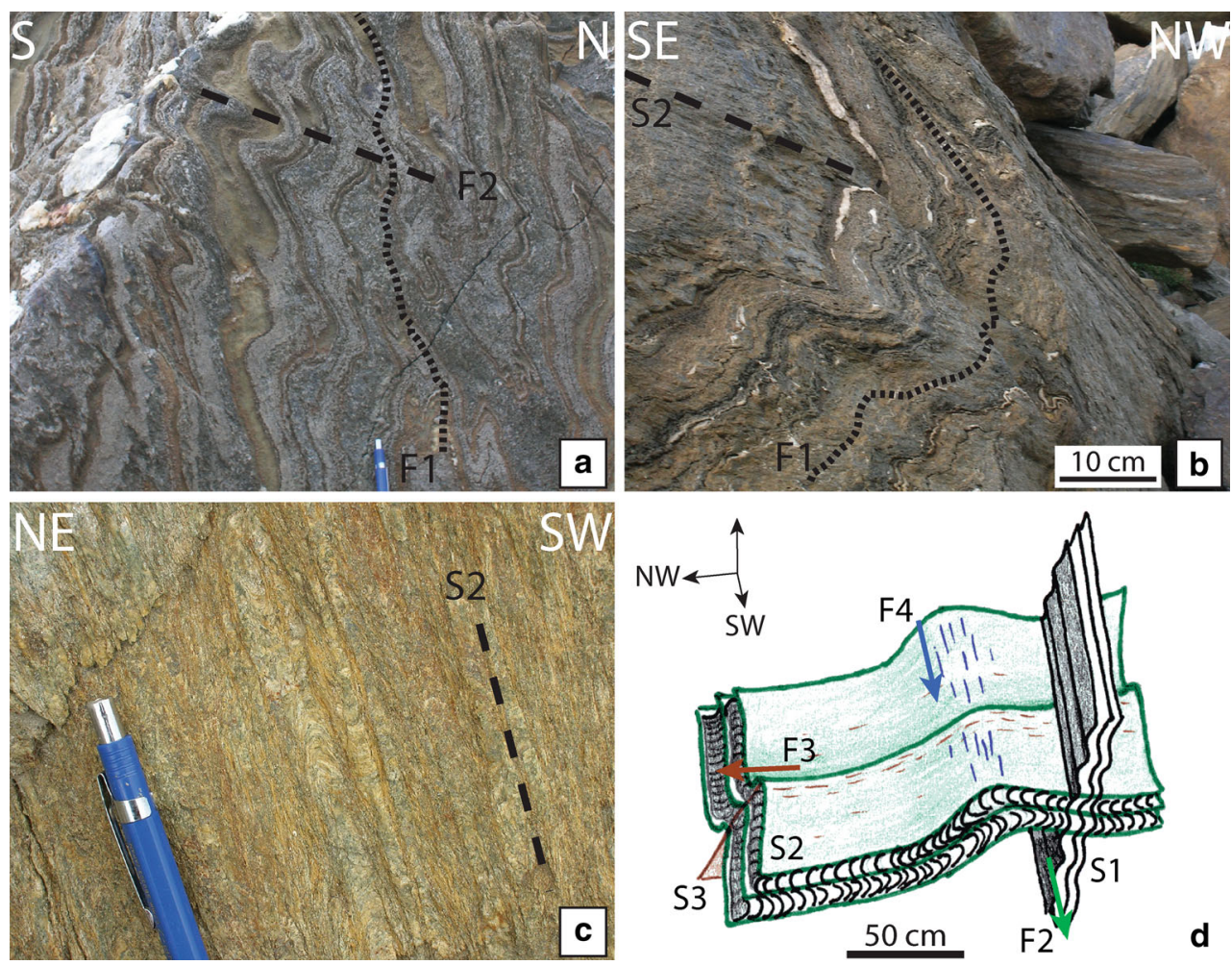


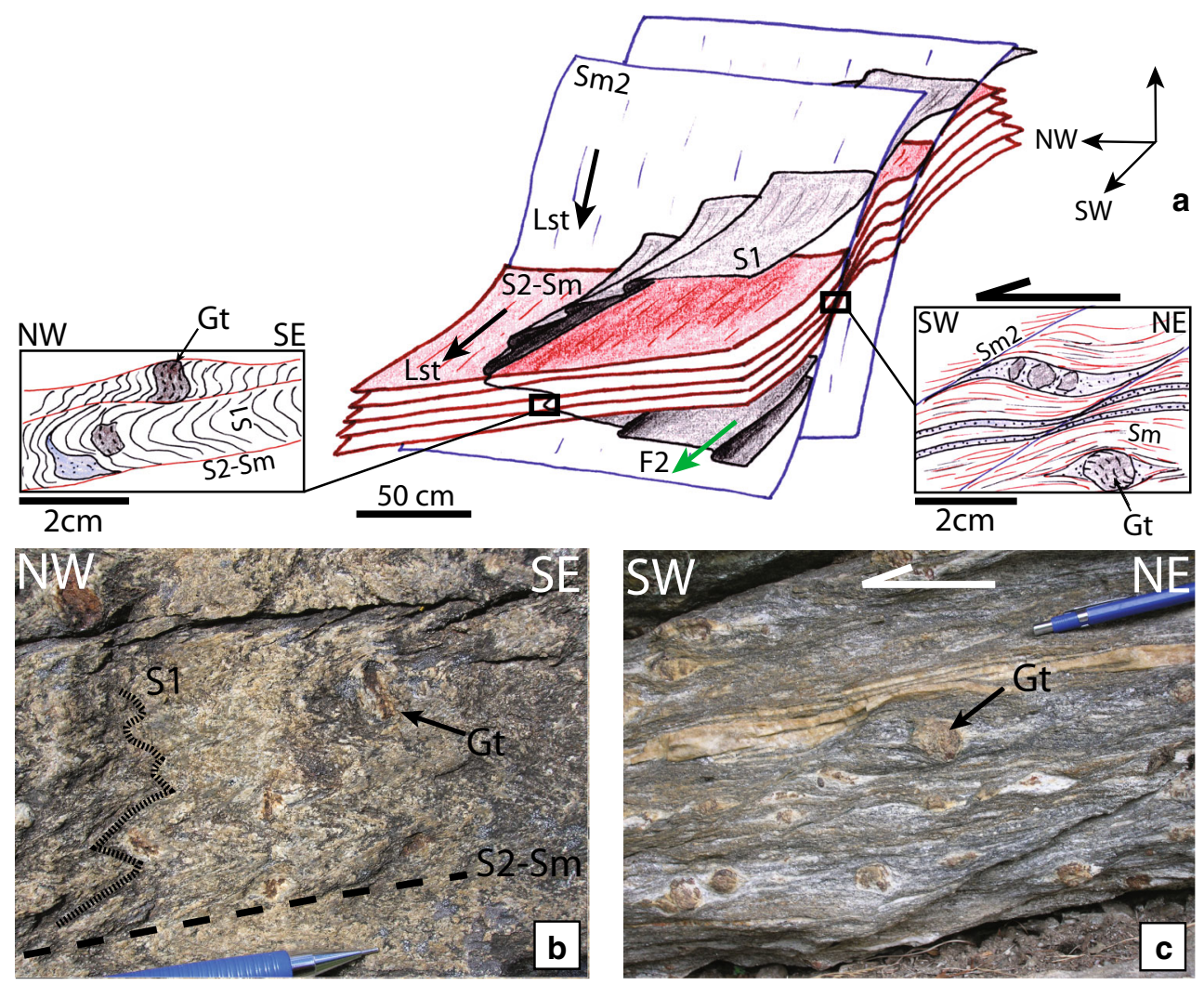

Fig. 6 Overprint of earlier deformation structures by the SFZ. a Synthetic sketch showing the reactivation of a pre-existent $S_{1 / 2}$ fabric on an outcrop scale (647034/122940). b F2 folds overprinted by the growth of garnet at peak metamorphic conditions, micaschist

(Fig. 5d). Overprinting relationships of these variably developed pre-existing deformation phases are observed within both the footwall and hanging-wall of the SFZ.

In the footwall, in the vicinity of the SFZ (i.e. within $\sim 3 \mathrm{~km}$ of the Simplon Line), D2 folds (F2) associated with an axial cleavage $S_{2}$ are well preserved, as can be seen, for example at the Simplon Pass (Fig. 6a). In this area, garnet porphyroblasts that grew during the Lepontine metamorphism have been dated at ca. $30 \mathrm{Ma}$ (Vance and O'Nions 1992). These garnets clearly overgrow both F2 folds and $S_{2}$, implying prograde development of the $S_{2}$ fabric (Fig. 6b). Along a SW-NE profile, the same $S_{2}$ fabric is clearly overprinted by retrograde top-to-SW shearing, leading to the formation of asymmetric pressure shadows developed on stretched garnet porphyroclasts (Fig. 6c). Such structures are interpreted to reflect transposition of the previous prograde $S_{2}$ fabric into the retrograde Simplon shear zone. For the first few kilometres into the footwall, the new Simplon mylonitic foliation (i.e. the older and warmer Sm foliation as defined above) and the previous $S_{2}$ foliation are therefore effectively parallel (Fig. 6). Both fabrics are folded by the Berisal backfold and a distinction between this higher temperature Simplon (Sm) mylonitic foliation and $\mathrm{S}_{2}$ is not straightforward.

with garnet, Houillère Zone, footwall (647034/122940). c Retrograde top-to-SW shearing with asymmetric pressure shadows developed on stretched garnet porphyroclasts, micaschist with garnet, Houillère Zone, footwall (647034/122940)

Indeed, Steck (1990, 2008) and Steck et al. (2013) argued that the older Simplon mylonitic foliation in effect developed as part of a wide D2 shear zone (his "dextral Simplon ductile shear zone") associated with longitudinal NE-SW trending stretching lineations (his XII) that could be observed both within the footwall and the hanging-wall. In the Malesco area of the Centovalli, further to the southeast and closer to the Periadriatic (or Insubric) Fault, this wide D2 shear zone is cut by porphyritic dikes dated at 31-29 Ma (Romer et al. 1996), providing a minimum age for this deformation (Steck 2008; Steck et al. 2013).

In the central region (region I, Fig. 1b), the Simplon Line clearly crosscuts the fabric $S_{1 / 2}$ of the hanging-wall and further north (region III, Fig. 1b), it also transects the backfolded higher grade $\mathrm{S}_{1 / 2 / \mathrm{Sm}}$ foliation in the footwall (Fig. 1; cf. Fig. 2 of Mancktelow 1992; Fig. 5 of Steck 2008). However, toward the southeast (region II, Fig. 1b), foliation planes within footwall and hanging-wall have a parallel strike and no clear geometrical discontinuity in the structural trend is observed. As a result, the prolongation of the SFZ in this region was controversial and Keller et al. (2005) have argued that the SFZ did not continue to the southeast and that the footwall and hanging-wall fabrics were indistinguishable. 


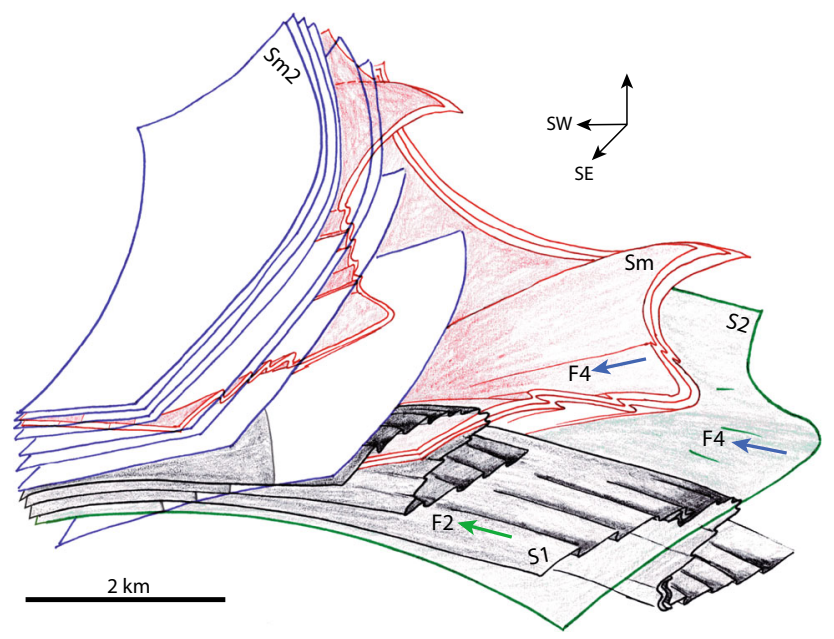

Fig. 7 Synthetic sketch of the complexly deformed region around the Simplon Pass, showing the overprinting relationships. Sm2: younger ductile-to-brittle mylonitic foliation related to the SFZ; Sm: older ductile mylonitic foliation related to the SFZ; $\mathrm{S}_{1}$ and $\mathrm{S}_{2}$ : pre-existent regional fabric associated with the D1-D2 deformation phase; F2: Fold axis related to the tight to isoclinal post-nappe refolding D2, F4: Fold axis related to the D4 backfolds in the Northern Steep Belt

In summary, it is clear that the SFZ low-angle detachment system affects an already complexly deformed region, showing overprinting relationships between several deformation phases, and that this leads to an overall complex 3D geometry (Fig. 7). In this paper we mainly focus on the interplay between extensional faulting and upright folding corresponding to the most recent deformation phase, D4, affecting this complexly deformed region. However, characterisation of the SFZ older (Sm) and younger ( $\mathrm{Sm} 2)$ fabrics in comparison to the preexisting $\mathrm{S}_{1 / 2}$ fabric is also relevant in an attempt to establish the overall 3D geometry and development history of the SFZ.

\subsection{Chronological constraints}

\subsubsection{The Simplon Fault Zone}

Both the offset in mineral ages across the more discrete detachment and the differing history and pattern of cooling across the broader fault zone are clearly associated with relative displacement on the SFZ, and different models for the variation in exhumation in time and space have already been extensively discussed in the literature (e.g. Mancktelow 1992; Grasemann and Mancktelow 1993; Steck and Hunziker 1994; Campani et al. 2010a, b). Results obtained with a 2-3D thermo-kinematic model suggest that the onset of faulting was at $18.5 \pm 2.5 \mathrm{Ma}$ (Campani et al. 2010a, b) and continued until at least $3 \mathrm{Ma}$, as reflected in the discontinuous cooling history across the
SFZ (Grasemann and Mancktelow 1993). Coupled ${ }^{40} \mathrm{Ar} /{ }^{39} \mathrm{Ar}$ and $\mathrm{Rb}-\mathrm{Sr}$ dating on muscovite growing in the undeformed neck of foliation boudinage within high-grade mylonites from the south-eastern region (region II, Fig. 1b), returned an age of ca. 14.5 Ma, which dates the transition from more ductile to more brittle deformation within fine-grained orthogneisses (Campani et al. 2010b). The same methods applied to syn-kinematic phengites in low-grade phyllonites from the north-western region (region IV, Fig. 1b) suggest that at least in these rocks from this region, the ductile-to-brittle transition lasted until more recent times around $10 \mathrm{Ma}$ (Campani et al. 2010b; Pleuger et al. 2012). Illite from clay gouge in the brittle detachment was previously dated with the $\mathrm{K} / \mathrm{Ar}$ method at $7.17 \pm 0.18 \mathrm{Ma}$ for the $<2 \mu \mathrm{m}$ fraction (Zwingmann and Mancktelow 2004). The age constraints and evolution of the SFZ from the ductile to the brittle field during the Miocene are therefore quite well established.

\subsubsection{Extension-orthogonal folds}

The decrease in dip of the pervasive foliation into the footwall corresponds to a broad 'fold' with an axis perpendicular to the extension direction. This broad structure has been interpreted to be coeval with shear zone activity and to reflect either a strain gradient through the shear zone (Mancktelow 1992; Mancktelow and Pavlis 1994) or a rolling hinge structure (Wawrzyniec et al. 1999, 2001). In the south-eastern section (region II, Fig. 1b), a slight jump in ${ }^{40} \mathrm{Ar} /{ }^{39} \mathrm{Ar}$ and $\mathrm{Rb}-\mathrm{Sr}$ cooling ages is observed across the SFZ between 17 and $14 \mathrm{Ma}$ (Campani et al. 2010b). This is attributed to minor differential displacement between footwall and hanging-wall, introduced by the regional up-doming of the footwall during the penetrative ductile shear, as indicated by the change in plunge direction of the stretching lineation (Fig. 1a). However, no significant offset in cooling ages is indicated by lowtemperature zircon and apatite fission track results after ca. $14 \mathrm{Ma}$ (Keller et al. 2005). This may be attributed to the fact that late brittle dextral strike-slip movement on the SFZ postdates regional up-doming of the footwall, which may have ceased or strongly diminished at the time of the ductileto-brittle transition, in this region around 14.5 Ma (Campani et al. 2010b).

\subsubsection{Extension-parallel folds}

Backfolds from the Southern and Northern Steep Belts (with axes parallel to the SFZ extension direction) are not generally considered to be coeval structures (e.g. Steck and Hunziker 1994; Maxelon and Mancktelow 2005). The steep fabric of the Southern Steep Belt is crosscut by 

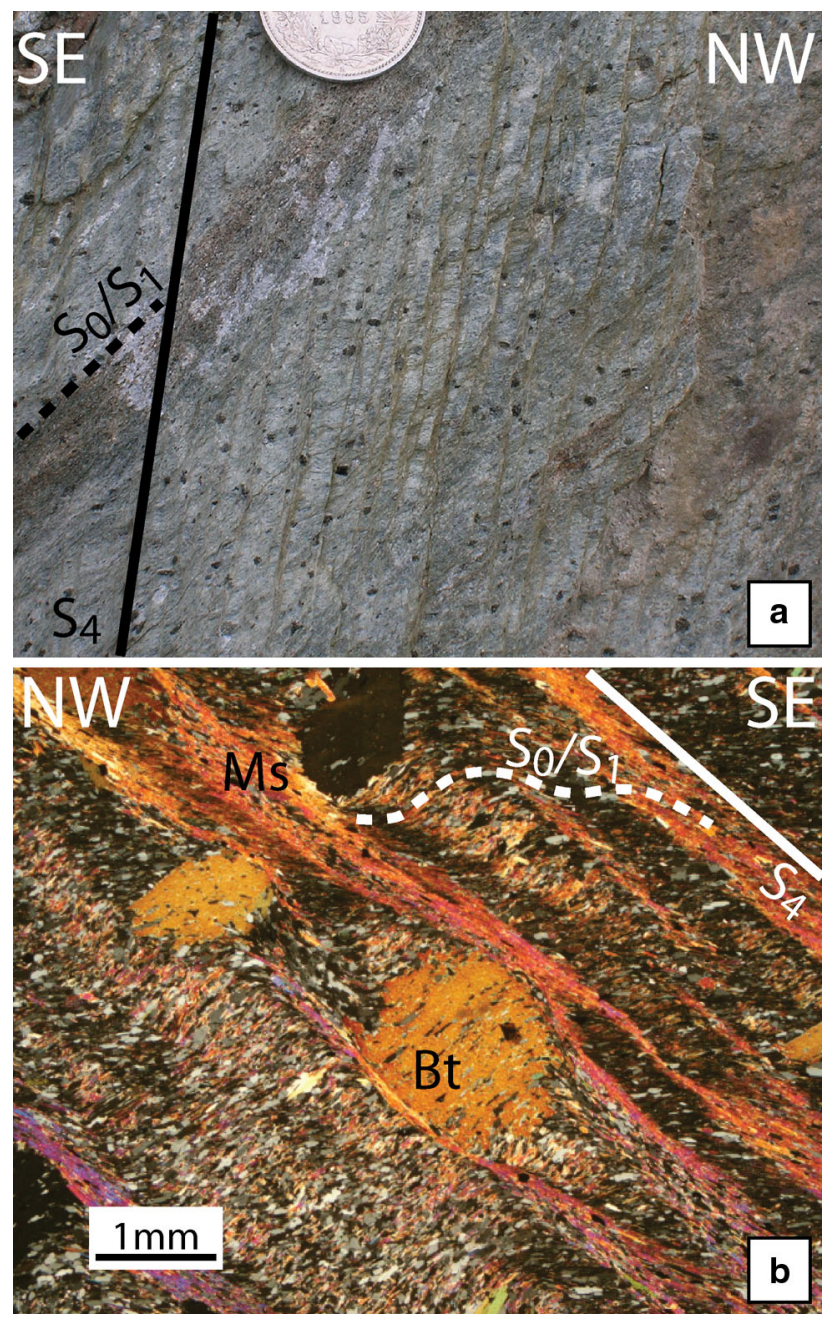

Fig. $8 \mathrm{~S}_{4}$ crenulation cleavage developed in meta-pelite (sample MC301) from the southern limb of the Glishorn antiform, Urseren zone, footwall (647656/134493). Ms muscovite, $B t$ biotite, $S_{0} / S_{1}$ composition banding or old $\mathrm{S}_{1}$ fabric, $S 4 \mathrm{~S}_{4}$ axial plane cleavage

pegmatite and aplite dykes dated at ca. $25 \mathrm{Ma}$ (e.g. Romer et al. 1996). Pettke et al. (1999) also reported direct muscovite ${ }^{40} \mathrm{Ar} /{ }^{39} \mathrm{Ar}$ dating from undeformed gold veins that crosscut the axial plane of the Vanzone antiform. The age of these veins decreases toward the northeast, varying from $32 \mathrm{Ma}$ in the Brusson area to $24.5 \mathrm{Ma}$ closer to the Simplon detachment. These results give a minimum age for the end of significant Vanzone fold activity and the Southern Steep Belt is therefore interpreted to develop in the Oligocene, prior to $25 \mathrm{Ma}$.

In the Northern Steep Belt, the age of the Berisal and Glishorn backfolds is less well established. Steck and Hunziker (1994) noted that the 12 Ma biotite $\mathrm{Rb}-\mathrm{Sr}$ isoage line is folded around the Berisal and Glishorn folds. These structures were therefore interpreted to be younger than $12 \mathrm{Ma}$ and to be associated with the young exhumation of the Aar massif as established from fission-track cooling ages (e.g. Michalski and Soom 1990). However, no direct dating was previously available to confirm the age of these structures in the Northern Steep Belt. In this paper, we provide new chronological constraints on the relative and absolute timing for the extension-parallel Berisal and Glishorn folds.

\section{Approaches and methods}

In this section, we outline the two main methods that have been employed to provide new constraints on the interplay between folding and faulting in the SFZ. The results from each method are presented in Sect. 4 and the significance of these results is discussed in Sect. 5 .

\section{$3.1{ }^{40} \mathrm{Ar} /{ }^{39} \mathrm{Ar}$ chronology}

In order to provide a direct chronological constraint on the formation of extension-parallel folds, we selected one strategic sample (MC 301) from a meta-pelite located within the Permian Urseren zone, which corresponds to the cover of the Gotthard massif in the Northern Steep Belt (Fig. 1). This meta-pelite equilibrated under upper greenschist facies metamorphic conditions (Frank 1983) and shows a strongly developed, steep crenulation cleavage dipping $82^{\circ}$ toward $152^{\circ}$ (Fig. 8). The relationship of this cleavage to the previous fabric $\left(\mathrm{S}_{(0) / 1}\right)$ indicates that this sample lies on the southern limb of an antiform (Fig. 8a), which is consistent with its location relative to the Glishorn antiform (Fig. 1). This crenulation cleavage corresponds in style and orientation to the $\mathrm{S}_{4}$ axial plane schistosity of the backfolds. In thin section (Fig. 8b), the main fabric $\left(\mathrm{S}_{(0) / 1}\right)$ is defined by thin white micas of ca. 10 to $80 \mu \mathrm{m}$ width and 80 to $200 \mu \mathrm{m}$ length. Large biotite porphyroblasts $(>500 \mu \mathrm{m})$ grew over $\mathrm{S}_{1}$ most probably during an upper greenschist facies metamorphic overprint. $S_{1}$ is affected by a strong crenulation cleavage $\left(S_{4}\right)$ mainly defined by thin flakes of white micas of ca. $10-20 \mu \mathrm{m}$ width and $60-130 \mu \mathrm{m}$ length. This crenulation cleavage clearly postdates the growth of the biotite porphyroblasts. As a first step, major elements of the different micas were analysed at ETH-Zürich with a JEOL-8200 EMPA equipped with wave length (WDS) and energy dispersive detectors. Beam conditions were defined by an acceleration voltage of $15 \mathrm{kV}$ and current of $2 \times 10^{-8}$ A. Beam diameter was $5 \mu \mathrm{m}$ for grains larger than $10 \mu \mathrm{m}$ and focused for grains smaller than $10 \mu \mathrm{m}$. For each element, counting times were $20 \mathrm{~s}$ on the peak and $10 \mathrm{~s}$ for the background, resulting in a detection limit of ca. $0.01 \mathrm{wt} \%$. Biotite and muscovite were then separated by hand-picking under a binocular microscope for ${ }^{40} \mathrm{Ar} /{ }^{39} \mathrm{Ar}$ dating, but the two generations of muscovite oriented parallel to $S_{1}$ and $S_{4}$ were not isolated. 
Table 1 Mean mica compositions from the meta-pelite sample MC301, with standard errors also listed

\begin{tabular}{|c|c|c|c|c|c|c|}
\hline & \multicolumn{4}{|c|}{ White mica } & \multirow{2}{*}{\multicolumn{2}{|c|}{$\frac{\text { Biotite }}{n=10}$}} \\
\hline & \multicolumn{2}{|c|}{$\mathrm{S} 1, n=16$} & \multicolumn{2}{|c|}{$\mathrm{S} 4, n=19$} & & \\
\hline & Mean & Error & Mean & Error & Mean & Errol \\
\hline $\mathrm{SiO}_{2}$ & 46.63 & 0.60 & 46.72 & 0.46 & 36.40 & 0.23 \\
\hline $\mathrm{TiO}_{2}$ & 0.36 & 0.06 & 0.38 & 0.03 & 1.58 & 0.09 \\
\hline $\mathrm{Cr}_{2} \mathrm{O}_{3}$ & 0.02 & 0.01 & 0.02 & 0.02 & 0.02 & 0.02 \\
\hline $\mathrm{Al}_{2} \mathrm{O}_{3}$ & 33.32 & 0.78 & 33.00 & 0.78 & 17.58 & 0.25 \\
\hline $\mathrm{FeO}$ & 3.40 & 0.14 & 3.34 & 0.19 & 19.36 & 0.19 \\
\hline $\mathrm{MnO}$ & 0.01 & 0.01 & 0.01 & 0.01 & 0.14 & 0.04 \\
\hline $\mathrm{MgO}$ & 1.41 & 0.20 & 1.45 & 0.17 & 10.45 & 0.04 \\
\hline $\mathrm{CaO}$ & 0.01 & 0.01 & 0.01 & 0.01 & 0.01 & 0.02 \\
\hline $\mathrm{Na}_{2} \mathrm{O}$ & 0.65 & 0.09 & 0.61 & 0.08 & 0.15 & 0.03 \\
\hline $\mathrm{K}_{2} \mathrm{O}$ & 9.42 & 0.23 & 9.39 & 0.26 & 9.25 & 0.21 \\
\hline Total & 95.23 & 0.43 & 94.93 & 0.26 & 94.94 & 0.29 \\
\hline
\end{tabular}

Footwall sample, Urseren Zone (Swiss coordinate system: 647656/134493). S1: old $S_{1}$ fabric; $S 4: S_{4}$ axial plane cleavage to the Berisal and Glishorn backfolds, related to development of the Northern Steep Belt

Micas were irradiated in the nuclear reactor at McMaster University in Hamilton (Canada). ${ }^{40} \mathrm{Ar} /{ }^{39} \mathrm{Ar}$ analysis was carried out by single-grain analysis with a $50 \mathrm{~W}$ SYNRAD $\mathrm{CO}_{2}$ continuous laser. Isotopic ratios were measured using a VG3600 mass spectrometer, working with a Daly detector system, at the University of Nice (Géosciences Azur, France). The typical blank values for extraction and purification of the laser system are in the range 4.2-8.75 and $1.2-3.9 \mathrm{~cm}^{3}$ STP for masses 40 and 39, respectively. Decay constants $\left(5.543 \times 10^{-10}\right.$ year $\left.^{-1}\right)$ are those of Steiger and Jäger (1977). Isotopic measurements are corrected for isotopic interferences of $\mathrm{K}, \mathrm{Ca}$ and $\mathrm{Cl}$, mass discrimination and atmospheric argon contamination. Uncertainties on individual apparent ages are given at the $1 \sigma$ level and do not include the error in the ${ }^{40} \mathrm{Ar}^{*} /{ }^{39} \mathrm{Ar}_{\mathrm{k}}$ ratio of the monitor $( \pm 0.2 \%)$. Uncertainties on plateau ages and integrated ages are given at the $2 \sigma$ level and do not include the error in the age of the monitor. Plateau ages are defined when at least $70 \%$ of ${ }^{39} \mathrm{Ar}$ is released over a minimum of three successive steps.

\subsection{D geometric modelling}

The geometry of the SFZ in 3D was modelled using the computer program GeoModeller, which is based on the mathematical representation of a geological surface using the potential field cokriging method (Lajaunie et al. 1997; Aug et al. 2005). This method uses a potential field function $T(x, y, z)$ interpolated by cokriging from points located on interfaces, which are considered to have a common potential value for each interface, and from directional data representing the gradient of $T$, which are not necessarily located at interface points. The effect of faults is modelled by introducing a discontinuous external drift function in the cokriging system. Thanks to the dual form of this cokriging approach, once the system has been solved it can be used an interpolator, so that estimates of $T$ at any point $p$ in space can be easily made. This property allows each interface to be considered as a specific isovalue of the potential field and the method is therefore particularly appropriate for determining foliation trajectories in $3 \mathrm{D}$.

Two types of input data are used: (1) interfaces (lithology, stratification, foliation, fault, axial plane) considered as equipotential points $p$ of a fictive scalar field; and (2) geological measurements (dip, dip direction, polarity) corresponding to the orientation of the interface, with a sense given by the polarity. Such measurements are considered as the gradient (i.e. derivative) of the potential field. Faults are included and modelled as a discontinuity in the potential field. A complete geological model is made up of different potential fields, which are assembled with respect to their chronology and relationships by combining these different fields into one function, which associates a geological formation to some point in space (Calcagno et al. 2008). It is the exploitation of this function that allows different visual representations of the model as maps, sections, 3D representations, and meshes.

We follow a similar approach to that developed by Maxelon and Mancktelow (2005) and Maxelon et al. (2009). We present three geometric models of increasing complexity that consider the fault zone geometry (the discrete detachment and the planar fabrics $\mathrm{Sm}$ and $\mathrm{Sm} 2$ ) relative to the previous (composite) fabric within the footwall and hanging-wall $\left(\mathrm{S}_{1 / 2}\right)$. The foliation field model was built using a large database of hundreds of foliation measurements (details and model set up are given in Sect. 4.2 for each geometric model). To visualise the resulting foliation field model in 3D, an arbitrary structural level has been chosen. All foliation measurements are given a polarity ( $1=$ normal; $-1=$ reverse) relative to the $\mathrm{D} 4$ deformation phase (including backfolds of the Northern and Southern Steep Belts and the SFZ overprint). Folds are specifically included in the models, with the axial planes established both from direct field measurements and from the axial trace on the surface topography. A local symmetry has been imposed along axial surfaces with a geometry similar to that observed for smaller-scale parasitic folds. However, folds are automatically generated by the 3D modelling and do not have to be explicitly included, although it can help to extend the geometry into regions where few foliation measurements are available. Such computer-generated, interpolated 3D models help to visualise the complex deformation pattern and to critically assess controversial field relationships. 
Table $2{ }^{40} \mathrm{Ar} /{ }^{39} \mathrm{Ar}$ stepwise heating data for sample MC301 (see Fig. 9)

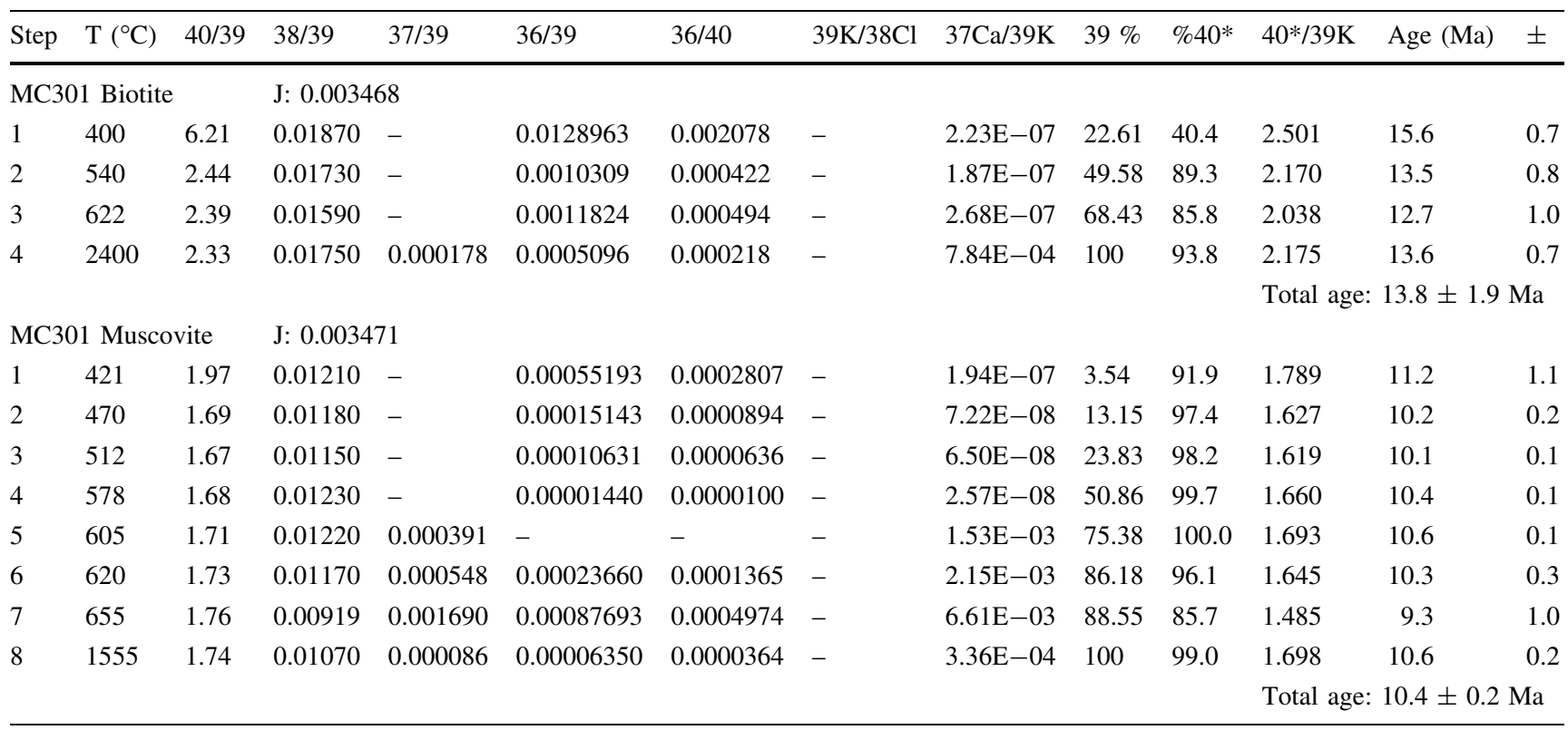

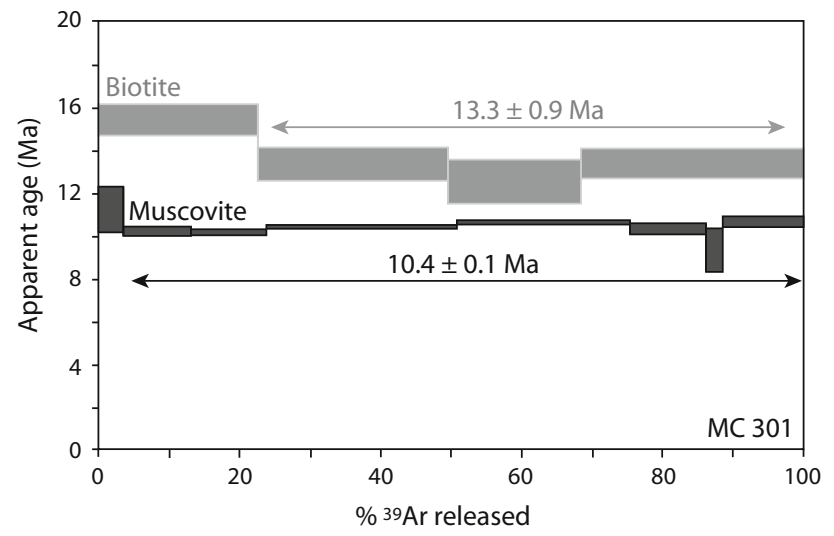

Fig. $9{ }^{40} \mathrm{Ar} /{ }^{39} \mathrm{Ar}$ age spectra for sample MC301 affected by $\mathrm{S}_{4}$ crenulation cleavage parallel to the axial plane of backfolds from the Northern Steep Belt

\section{Results}

\subsection{Dating of $\mathrm{S}_{4}$ axial plane cleavage}

Both generations of white micas $\left(\mathrm{S}_{1}\right.$ and $\left.\mathrm{S}_{4}\right)$ have similar muscovite compositions (Table 1), suggesting that they grew under similar low P-T conditions (Guidotti 1973). Biotite and muscovite both yield late Miocene ${ }^{40} \mathrm{Ar} /{ }^{39} \mathrm{Ar}$ ages (Table 2), with plateau ages of $13.3 \pm 0.9$ and $10.4 \pm 0.1 \mathrm{Ma}$, respectively (Fig. 9). The muscovite presents a stronger signal with a better defined ${ }^{40} \mathrm{Ar} /{ }^{39} \mathrm{Ar}$ age spectra characterised by a larger single step of ${ }^{39} \mathrm{Ar}$ release.

In this region, the greenschist metamorphism overprint did not reach more than $400-420{ }^{\circ} \mathrm{C}$ (Frank 1983) and only led to a partial loss of ${ }^{40} \mathrm{Ar}$ in pre-Alpine micas, yielding total ${ }^{40} \mathrm{Ar} /{ }^{39} \mathrm{Ar}$ ages ranging between Alpine and pre-Alpine ages and very disturbed age spectra in these old micas (Campani et al. 2010b). New white micas that grew under such low temperatures therefore provide reliable crystallisation ages. In this region, the closure temperature for biotite (ca. $320^{\circ} \mathrm{C}$ ) is predicted to be around $70{ }^{\circ} \mathrm{C}$ lower than that of white mica (ca. $390{ }^{\circ} \mathrm{C}$ ) and cooling ages should therefore yield younger ages for biotite than for muscovite (Campani et al. 2010a, b). However, the measured muscovite age is instead younger than the one for biotite and we therefore interpret the muscovite age to be a crystallisation age rather than a cooling age. In contrast, for biotite, ${ }^{40} \mathrm{Ar} /{ }^{39} \mathrm{Ar}$ ages are always interpreted to reflect cooling ages, considering the low closure temperature. $\mathrm{The}{ }^{40} \mathrm{Ar} /{ }^{39} \mathrm{Ar}$ biotite cooling age of $13 \mathrm{Ma}$ therefore provides a minimum age for biotite growth and thus for the overprint of the main fabric $S_{1}$. Note that the muscovite age could correspond to $S_{1}, S_{4}$ or a mixture of both. The age of $10 \mathrm{Ma}$ could therefore reflect a mixed-age between the formation of $S_{1}$ and $S_{4}$, providing the maximum age for the development of the crenulation cleavage $S_{4}$. However, mixed-ages are typically characterised by an increasing staircase spectra (e.g. Campani et al. 2010b), which were not observed in this case. In thin section (Fig. 8b), only the muscovite growing within the crenulation cleavage $\mathrm{S}_{4}$ postdates biotite growth $(\geq 13 \mathrm{Ma})$. We therefore relate the crystallisation age of the muscovite, at ca. $10 \mathrm{Ma}$, to the development of the crenulation cleavage $\mathrm{S}_{4}$, and thereby date backfold development in the Northern Steep Belt. 


\subsection{D geometric modelling}

\subsubsection{Geometry of the last deformation phase D4 within the footwall}

In model 1 (Fig. 10), we first focus on the footwall of the SFZ. The goal is to visualise the last deformation phase affecting the tectonostratigraphic pile, including the effect of both extensional faulting and upright folding. To this end, we only consider the dominant fabric of the Simplon region, $S_{1 / 2}$, which is broadly parallel to the Simplon mylonites in the vicinity of the fault zone. These foliation measurements are presented in Fig. 10a to illustrate the density of orientation data available and thereby to also highlight where the model is best constrained. The input structural data interpolated in model 1 are provided in the Online Resource 1. The foliation field model of the dominant fabric within the footwall is then computed. To visualise the resulting foliation field model, we arbitrarily fix a structural level with one single interface point within the footwall (orange dot in Fig. 10a). The result is given in Fig. 10b in map view (effectively representing a map of the footwall foliation trajectories) and in Fig. 10c-e in 3D for one single foliation plane. A 3D animation is provided in the Online Resource 2. The Simplon Line (SL) trace on the topography is also shown for reference. This model reproduces the 3D geometry of the axial plane fabric of older deformation phases $\left(\mathrm{D}_{1}\right.$ and $\left.\mathrm{D}_{2}\right)$ deformed by the combined effect of SW extension and upright folding during unroofing. The geometric model reveals two structural culminations referred to as the Aar culmination and the Toce Dome (e.g. Steck and Hunziker 1994) in the footwall of the SFZ (Fig. 1a). We observe in Fig. 10b that $\mathrm{S}_{1 / 2}$ is parallel to the Simplon Line in the Toce Dome, but is clearly folded by the backfolds in region III (Fig. 1b) and discordant to the Simplon Line. In region IV, on the southern border of the Aar culmination, $S_{1 / 2}$ is clearly crosscut by the Rhone-Simplon Line, and similarly in region II, in the southeast, $S_{1 / 2}$ is again not parallel to the Simplon Line. In this area, the Simplon Line also clearly obliquely crosscuts the southern limb of the $\mathrm{D}_{2}$ Wandfluhorn fold (Fig. 1a; e.g. Milnes 1974).

\subsubsection{Geometry of the Simplon Fault Zone}

In model 2 (Fig. 11), we now add the fault zone geometry, including the older $(\mathrm{Sm})$ and younger (Sm2) Simplon foliation planes and the brittle detachment (SL), which are all considered as equipotential interfaces. The input data for the fault zone orientations have been presented in Campani et al. (2010b) and are provided here in the Online Resource 1. Figure 11a again only illustrates the density of the dataset. The dip of the brittle detachment itself is built based on geomorphological criteria, using the dip slopes of the topography of the footwall unit just below the detachment. To visualise the resulting foliation field model within the footwall, we fix one interface point for Sm (blue dot in Fig. 11a). For an optimal representation of $\mathrm{Sm} 2$, we increased the number of interface points to four (green dots in Fig. 11a), as less orientation data are available. The resulting model of the foliation field is given in a crosssection parallel to the extension direction in Fig. $11 \mathrm{~b}$ and in 3D in Fig. 11c-e. A 3D animation is provided in the Online Resource 2. In region I and III (Zwischbergen Valley and Engiloch locations, Fig. 1a, b), the dip of the Simplon Line is confirmed to be $25^{\circ}$ and $30^{\circ}$, respectively. The younger low grade fabric $(\mathrm{Sm} 2)$ shows the same strike as the detachment, whereas the older fabric (Sm) is clearly folded in the Northern Steep Belt, analogous to $\mathrm{S}_{1 / 2}$ (Fig. 11b-d). We note that the older Simplon mylonitic foliation $(\mathrm{Sm})$ has a domal geometry affected by two sets of folds, with both extension-parallel (Berisal and Glishorn) and extension-perpendicular fold axes. It is also seen that this $\mathrm{Sm}$ foliation is parallel to the previous $\mathrm{S}_{1 / 2}$ fabric in the vicinity of the SFZ (Fig. 11b, d). However, in two regions, clearly different orientations of the previous fabric $S_{1 / 2}$ and the older Simplon foliation (Sm) are observed (Fig. 11d): (1) in region IV, on the southern border of the Aar culmination, and (2) in region II to the southeast. In these two regions, $\mathrm{Sm}$ is parallel to the brittle Simplon Line and to the younger $\mathrm{Sm} 2$ fabric, whereas $S_{1 / 2}$ is crosscut by the Simplon Line (Fig. 10b). In these specific areas, Sm and $\mathrm{S}_{1 / 2}$ can be distinguished within the footwall as two different planar fabrics. In general, the ductile-to-brittle overprint associated with the younger low-grade Simplon foliation ( $\mathrm{Sm} 2)$ and the discrete brittle detachment are parallel and do not show any domal geometry. However, they are affected by open wavy folds (Fig. 11e), with fold axes parallel to the regional extension direction.

\subsubsection{Geometry of the hanging-wall}

Model 3 considers in addition the overprint of the last deformation phase within the hanging-wall, again using the dominant fabric $S_{1 / 2}$ as shown in Fig. 12a. The input structural data interpolated in model 3 are provided in the Online Resource 1 . To visualise the resulting foliation field model, we fix two structural levels within the hanging-wall, using one interface point for each structural level (blue and grey dots in Fig. 12a). The resulting foliation field model is presented in Fig. 12b in map view and in Fig. 12c as a cross-section through the Southern Steep Belt and perpendicular to the extension direction. The Fig. 12d-f present the 3D model of the foliation field in the hangingwall and its relationship to the Simplon Line. A 3D animation is provided in the Online Resource 2. It is clearly 

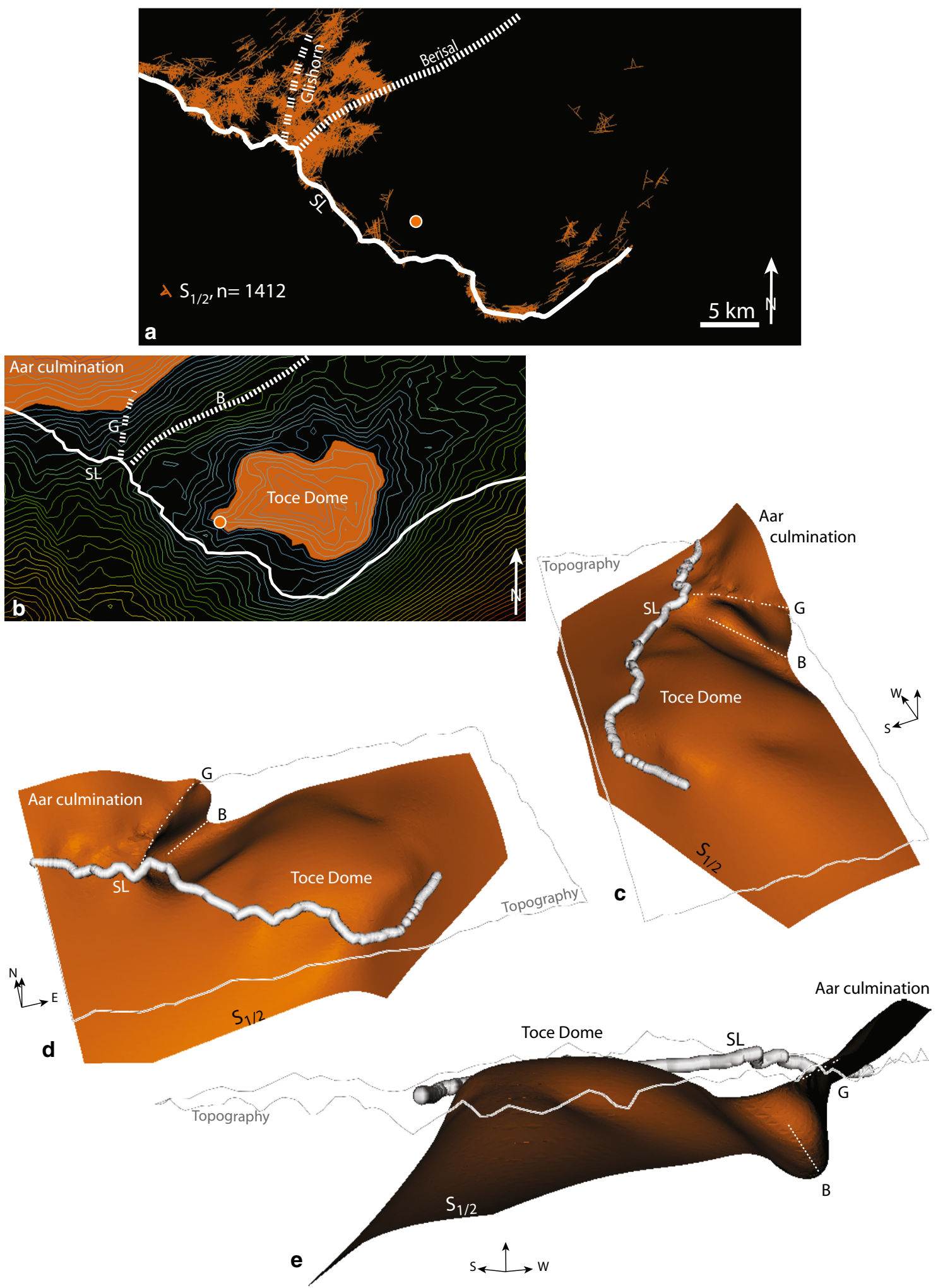

Fig. 10 Model 1: Footwall geometry $\left(S_{1 / 2}\right.$ and the last deformation phase D4). a Input data on the topography surface (foliation measurements and interface point). b Map view of the modelled footwall foliation field of the $S_{1 / 2}$ fabric on the topographic surface. Each line of different colour highlights the different values of the potential field. Such a representation is used to represent an $S_{1 / 2}$ foliation map. The crosscutting relationships between $S_{1 / 2}$ and the Simplon Line are clear at the NW and SE extremities of the Simplon Line. c-e 3D geometry of the modelled foliation field for $S_{1 / 2}$ represented as one single surface from different viewpoints. $B$ Berisal synform, $G$ Glishorn antiform, $S L$ Simplon Line, $S_{1 / 2}$ Pre-existent regional fabric associated with the D1-D2 deformation phase 

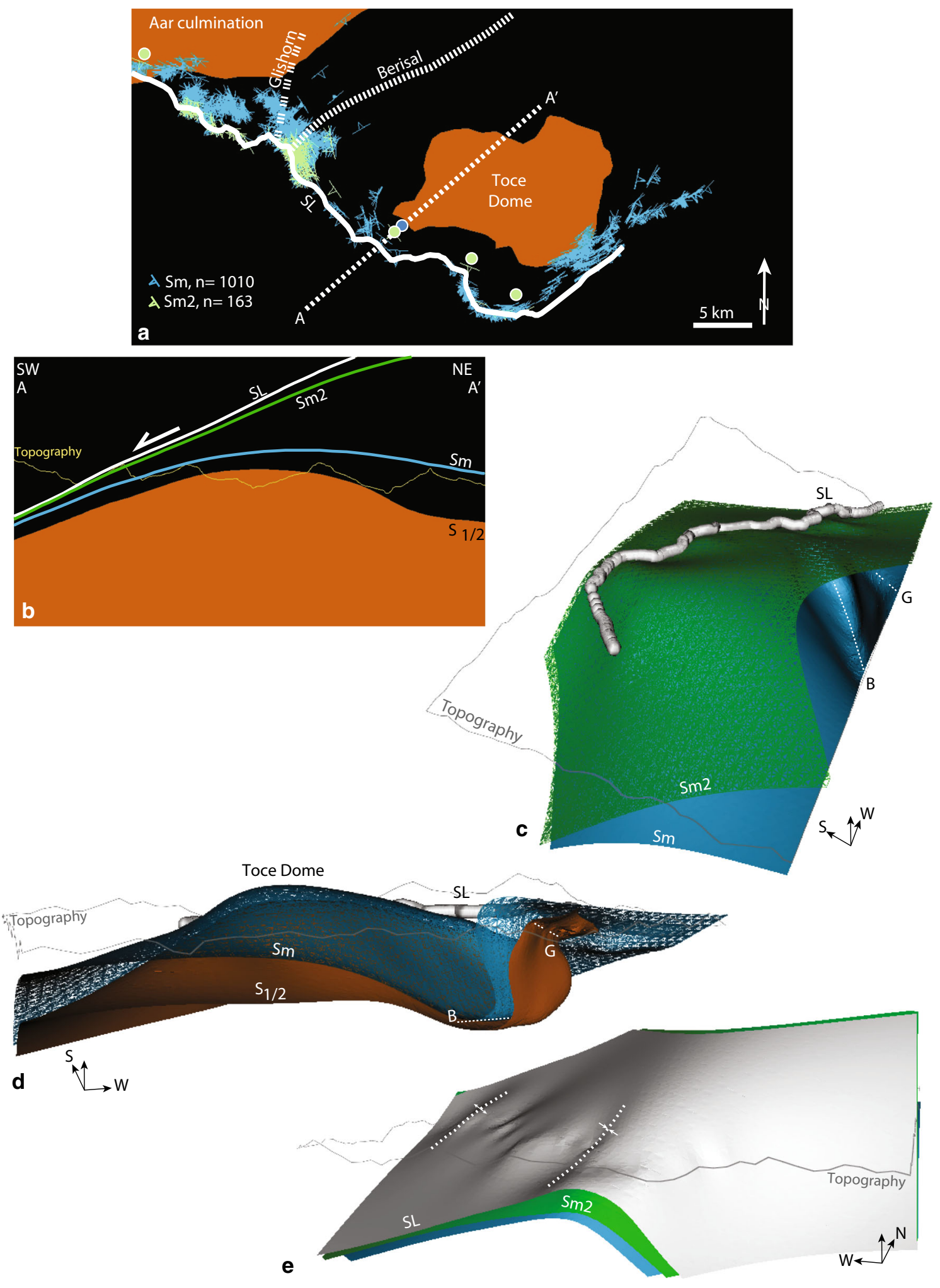
4Fig. 11 Model 2: Simplon Fault Zone geometry. a Input data on the topography surface using two sets of foliation measurements and interface points. For an optimal representation of $\mathrm{Sm} 2$ near the brittle detachment, the number of interface points has been increased to 4 (green dots), as less orientation data are available. b Section parallel to the extension direction showing the fault zone geometry. The older Simplon mylonites $(\mathrm{Sm})$ show a domal shape while the younger fabric (Sm2) is parallel to the brittle detachment (SL). c 3D geometry of the modelled foliation field for the older (Sm) and younger (Sm2) Simplon mylonitic fabrics. In contrast to $\mathrm{Sm} 2, \mathrm{Sm}$ is clearly folded around the Berisal and Glishorn backfolds. d 3D geometry of the older Simplon mylonites (Sm), showing the reactivation of the preexistent fabric $S_{1 / 2}$ in the core of the dome (Toce Dome) and the crosscutting relationship in the Aar culmination (to the west of the Glishorn antiform). e Wavy folds with axes parallel to the extension direction affecting the brittle detachment. $B$ Berisal synform, $G$ Glishorn antiform, $S L$ Simplon Line, Sm2 younger ductile-tobrittle mylonitic foliation related to the SFZ, Sm older ductile mylonitic foliation related to the SFZ, $S_{1 / 2}$ pre-existent regional fabric associated to the D1-D2 deformation phase

seen that in the central region the hanging-wall fabric is crosscut by the Simplon detachment. The Southern Steep Belt is plainly revealed in the hanging-wall of region II (Fig. 1b), with the $S_{1 / 2}$ fabric folded around the Vanzone antiform. In this region, the strike of the hanging-wall fabric is parallel to the strike of the SFZ (Fig. 12b). However, in Fig. 12c, in cross-section, the two fabrics are not strictly parallel. The northern limb of the Masera synform has a shallower dip than the SFZ toward the SE and a slightly discordant relationship is still observed in this region, which supports the proposed continuation of the SFZ (and more discrete Simplon Line) into and along the Isorno Valley (Fig. 1a). The model also predicts that the fault zone crosscuts the southern limb of the Vanzone antiform (Fig. 12c). The interpretation of such a geometry is discussed further below.

In summary, by using the dominant foliation measured in the Simplon region we can model the regional Toce Dome geometry, reflecting the coupled effect of both the SFZ and the overprint of the Southern and Northern Steep Zones (Fig. 10). These models also reveal the 3D fault zone geometry (Fig. 11) and its relationships with the earliest fabric within the footwall and hanging-wall (Figs. 10, 12).

\section{Discussion}

\subsection{Initiation of the Toce Dome}

Although no direct dating is available to constrain the age of formation of the Toce domal structure, the 3D structural relationships combined with the existing interpretations of the cooling pattern across the fault zone allow a potential scenario to be proposed and discussed.

\subsubsection{The broad extension-perpendicular antiform of the Toce Dome}

The flattening or bending of the foliation within the dome (Fig. 11f) was considered by Wawrzyniec et al. (1999, 2001) to represent a rolling hinge structure and by Mancktelow (1992) and Mancktelow and Pavlis (1994) to represent a strain gradient away from the shear zone, reflecting distributed ductile shear within the footwall. This strain gradient is also reflected in changes in recrystallisation processes (dynamic recrystallised grain size, crystallographic preferred orientation, and deformation mechanisms) toward the fault plane and results from strain localisation during ongoing cooling and unroofing of the footwall (Härtel 2012; Haertel et al. 2013). The 3D geometric model 2 (Fig. 11) suggests that only the older Simplon mylonite foliation ( $\mathrm{Sm}$ ) shows a domal shape but not the younger greenschist facies mylonite foliation (Sm2) or the late brittle and more discrete detachment. The 3D fault zone geometry therefore does not support a rolling hinge model for the SFZ. Campani et al. (2010a, b) also noted that the cooling pattern expected during exhumation associated with a rolling hinge kinematic model would not lead to the observed thermochronological ages within the Simplon footwall. We therefore also interpret this flattening of the foliation into the footwall to directly reflect the independently documented strain gradient into the footwall away from the detachment, resulting in an overall monoclinal shape. This geometry was generated during heterogeneous ductile shearing and is only observed in the ductile mylonites $(\mathrm{Sm})$. Implicitly, this distributed ductile shearing finished with the transition from ductile-to-brittle behaviour at ca. 14.5 Ma in the south-eastern region; the lower grade Sm2 fabric also does not record this flattening of the foliation. The reversal in dip direction of the Toce Dome toward the northeast (Fig. 10) may be an inherited structure, preserving steepening and folding of the $S_{1 / 2}$ fabric associated with the older D3 phase of deformation related to the Maggia steep zone (Steck 1998; Maxelon and Mancktelow 2005).

\subsubsection{The broad extension-parallel antiform of the Toce Dome}

Unroofing along the SFZ in the Central Alps without involving a rolling hinge structure requires compensation by coeval perpendicular shortening and thickening of the crust (Mancktelow and Pavlis 1994; Avigad et al. 2001). We propose that the broad orogen-parallel antiform that forms the Toce Dome, with an axis parallel to the extension direction, initiated already with the onset of ductile shearing in the fault zone around $18.5 \mathrm{Ma}$ as a direct result of ongoing orogen-perpendicular shortening. The period of 

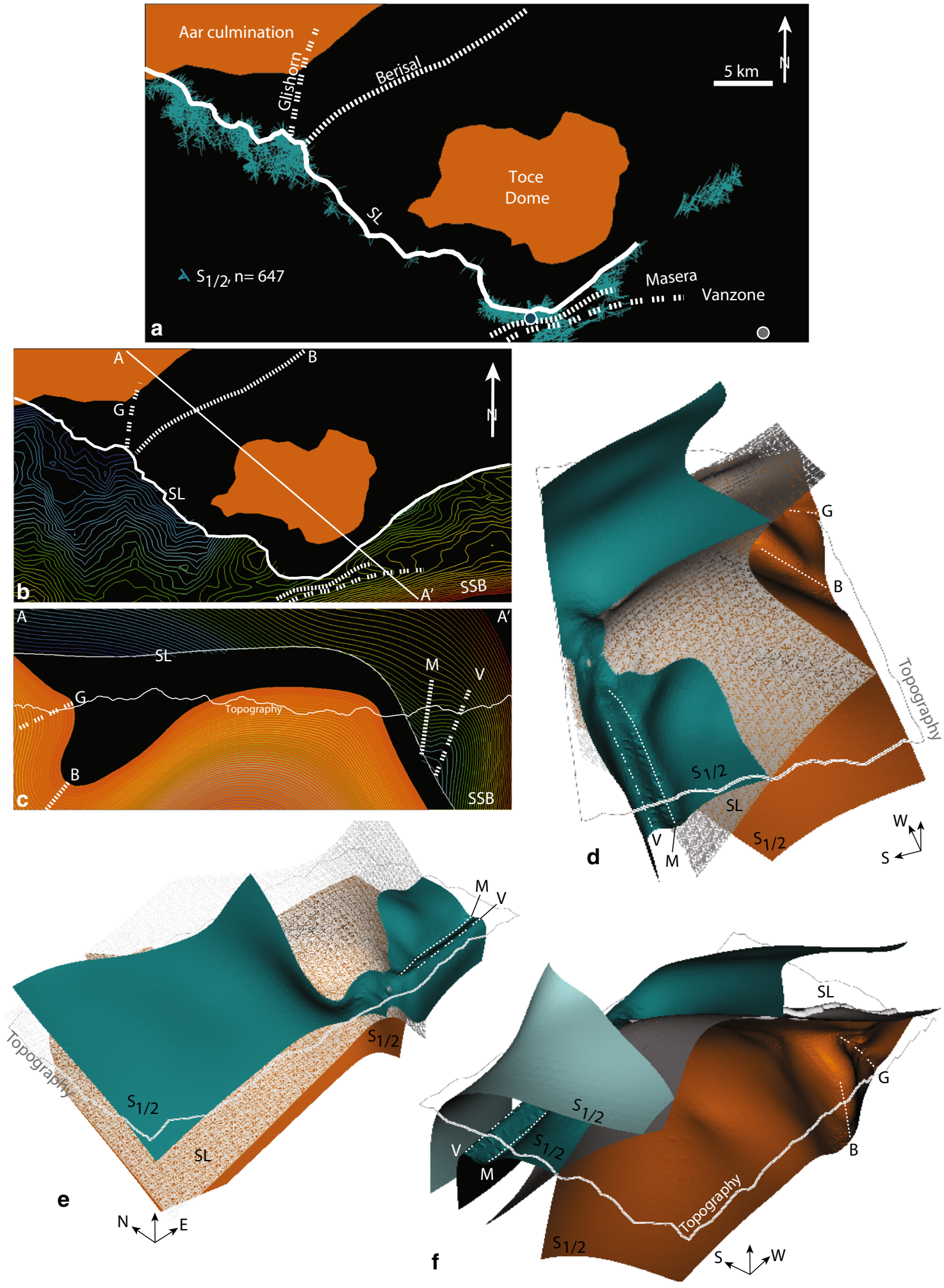

Fig. 12 Model 3: Hanging-wall geometry. a Input data on the topography surface (foliation measurements and interface points). b Map view of the modelled hanging-wall foliation field of the $S_{1 / 2}$ fabric on the topographic surface. Each line of different colour highlights the different values of the potential field. Such a representation is used to represent the $S_{1 / 2}$ foliation map within the hanging-wall. c Section perpendicular to the general extension direction showing the modelled foliation field of the $S_{1 / 2}$ fabric within footwall and hanging-wall. $\mathbf{d}-\mathbf{f} 3 \mathrm{D}$ geometry of the modelled foliation field for the $S_{1 / 2}$ fabric within footwall and hanging-wall and for the Simplon Line, from different viewpoints. $B$ Berisal synform, $G$ Glishorn antiform, $M s$ Masera synform, $V z$ Vanzone antiform, $S L$ Simplon Line, $S_{1 / 2}$ pre-existent regional fabric associated to the D1D2 deformation phase 
faster exhumation along the SFZ between 18.5 and 14.5 Ma (Campani et al. 2010a, b) most probably coincides with the time of main amplification of this antiform. Such an antiform developed during extension would explain why the maximum vertical displacement is localised within the central section of the fault zone and strongly diminishes toward both northwest and southeast (i.e. toward regions IV and II, respectively; Fig. 1b). The coeval horizontal NW-SE shortening on a continuously sheared top-to-SW fabric would produce an overall constrictional finite strain under upper greenschist to amphibolite facies conditions, as locally observed in region III (Fig. 3d).

To summarise, the doubly plunging antiform that forms the Toce Dome was generated synchronously with the onset of ductile shearing along the SFZ (Table 3; Fig. 13a, c, e) and reflects the combined effect of a strain gradient through the shear zone and perpendicular horizontal shortening due to ongoing convergence across the Alps.

\subsection{Development of the Northern Steep Belt}

The extension-parallel folds in the Northern Steep Belt affecting the footwall of the low-angle detachment system (SFZ) have been interpreted to be younger than $12 \mathrm{Ma}$, based on the folded $\mathrm{Rb}-\mathrm{Sr}$ iso-age line (Steck and Hunziker 1994). In this study, new ${ }^{40} \mathrm{Ar} /{ }^{39} \mathrm{Ar}$ dating of both preexisting and newly grown micas constrain the development of the axial plane $\mathrm{S}_{4}$ crenulation cleavage to be ca. $10 \mathrm{Ma}$, supporting a late Miocene backfold initiation. This age of $10 \mathrm{Ma}$ approximately corresponds to the time of the last ductile-to-brittle deformation and the onset of purely brittle fracturing along the SFZ in region IV (Fig. 1b, Rhone Valley) and along the southern border of the Aar massif (Mancktelow 1992; Campani et al. 2010b; Pleuger et al. 2012). The footwall of the SFZ preserves structures reflecting continuous exhumation from the ductile to the brittle field, over a time range from $18.5 \pm 2.5 \mathrm{Ma}$ to at least $3 \mathrm{Ma}$. The ductile-to-brittle transition of the fault rocks is dated at $14.5-14 \mathrm{Ma}$ in the southeast in finegrained orthogneisses (region II, Ossola Valley, Fig. 1b) and from 14 to $10 \mathrm{Ma}$ in the northwest in phyllonites (region IV, Rhone Valley, Fig. 1b; Campani et al. 2010a, b). The 3D geometric modelling clearly shows that the older ductile mylonitic foliation $(\mathrm{Sm})$ is strongly folded and transected by the younger greenschist facies mylonitic foliation (Sm2) and late brittle detachment (SL). Backfolds in the Northern Steep Belt that developed at around $10 \mathrm{Ma}$ therefore folded the already exhumed older ductile mylonites $(\mathrm{Sm})$. These folds were then further amplified during ongoing late slip associated with the younger more ductileto-brittle mylonites ( $\mathrm{Sm} 2)$ and the discrete brittle detachment (Table 3). The 3D geometric modelling shows clearly that both the brittle detachment and the greenschist facies mylonites are indeed also affected by wavy extensionparallel folds (Fig. 11e).

These results establish that extension-parallel folds in this region developed at around $10 \mathrm{Ma}$ during the late Miocene exhumation history of the SFZ. The new ${ }^{40} \mathrm{Ar} /{ }^{39} \mathrm{Ar}$ results therefore indicate that this backfolding, in contrast to the initiation of the Toce Dome, did not start with the onset of extension at ca. $18.5 \mathrm{Ma}$, as initially proposed by Mancktelow (1992) and Mancktelow and Pavlis (1994), but rather during or after the transition to more localised, lower temperature shearing concentrated at or close to the detachment (corresponding to the development of the younger Sm2 fabric and subsequent brittle faulting). For comparison, in the Eastern Alps, Rosenberg et al. (2007) suggest that local E-W extension along the equivalent Brenner Fault Zone was driven by an oblique indentation of the Adriatic microplate causing differential shortening in front of the indenter. If the extension-parallel

Table 3 Chronology of the different shear zones, faults and folds in the Simplon region

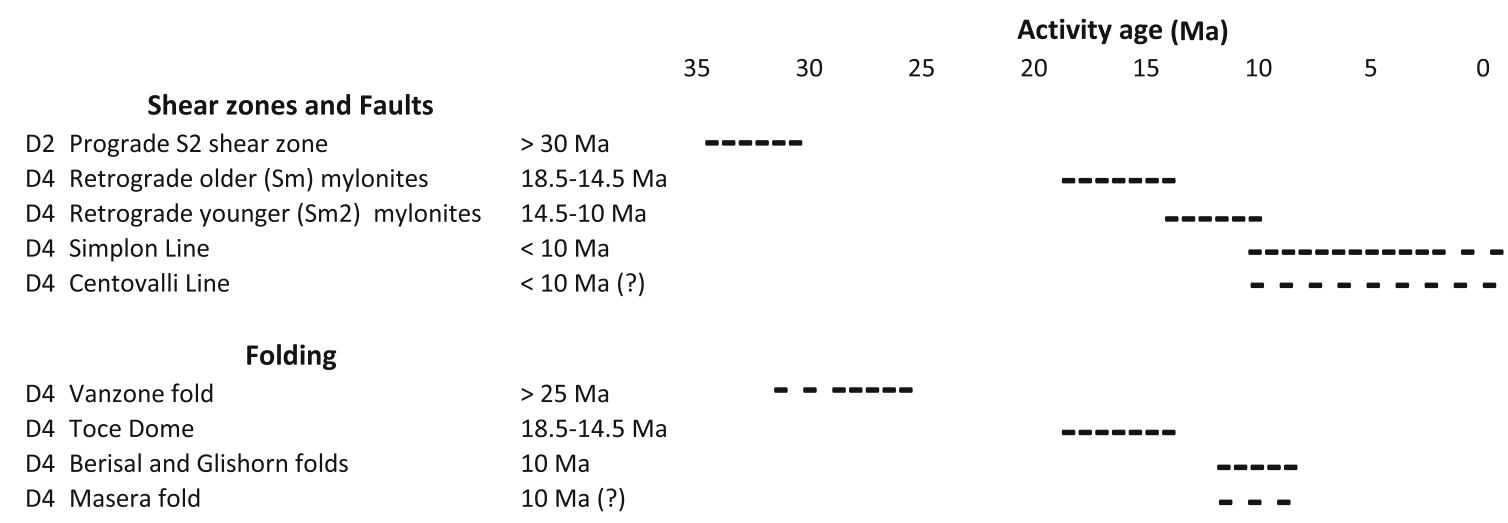



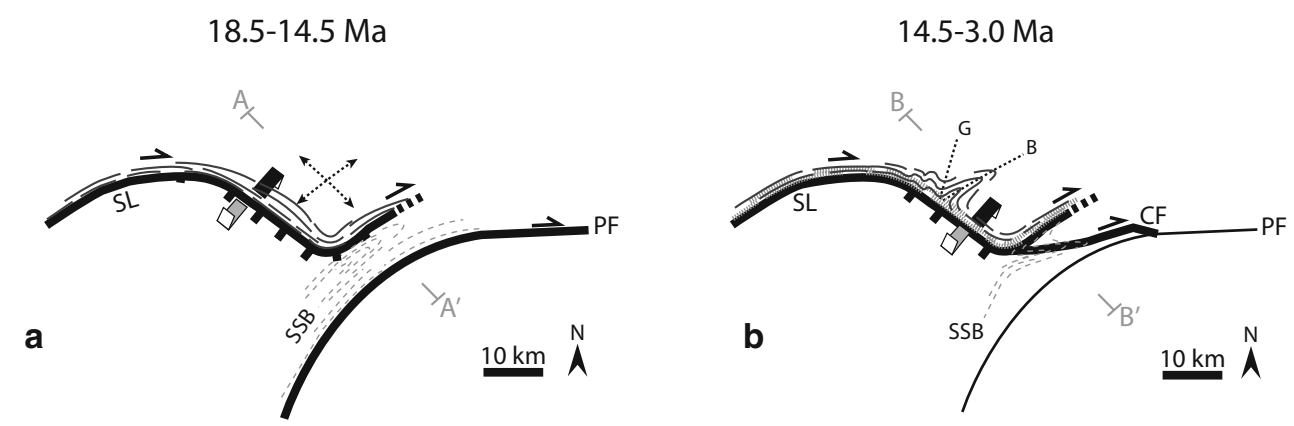

Scenario A
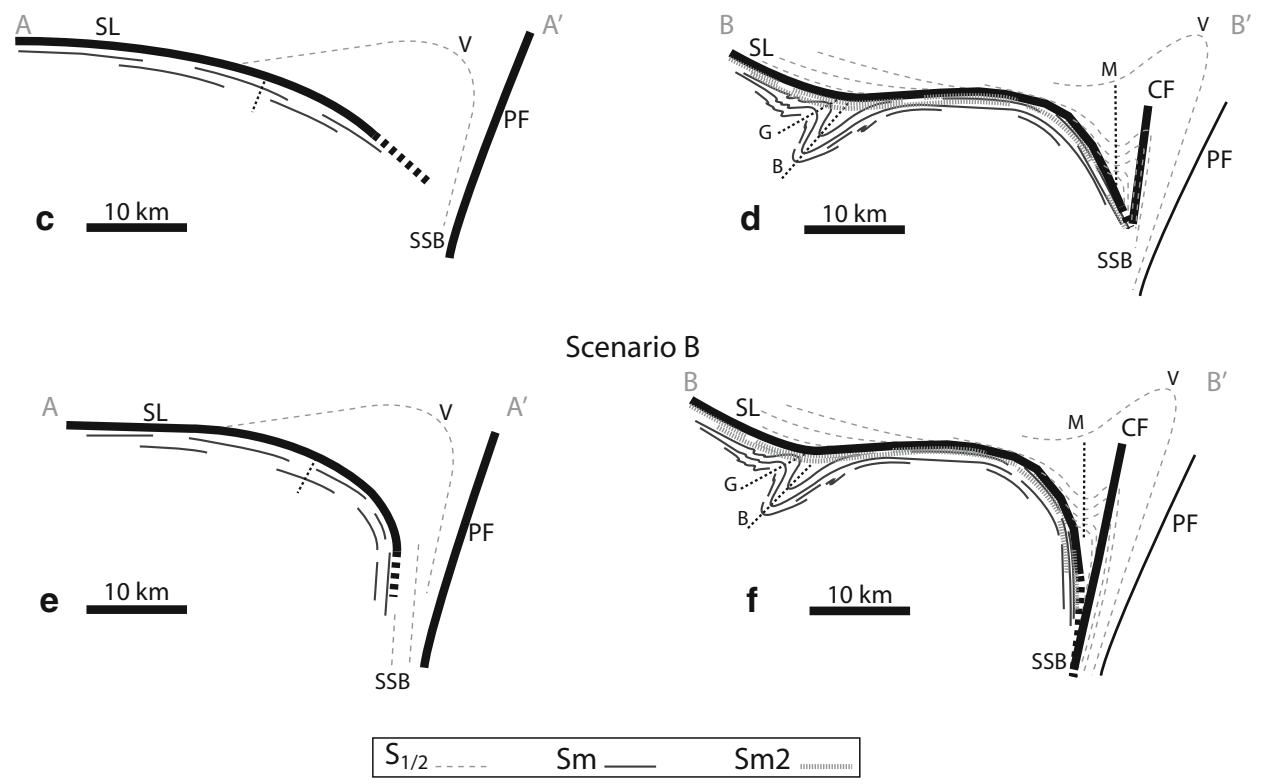

Fig. 13 Synthetic sketches of the SFZ evolution relative to the Southern Steep Belt. a, b Schematic structural map of the SFZ between 18.5-14.5 and 14.5-3 Ma. c, d Scenario A: NW-SE crosssection of an initially shallow SFZ crosscutting the Southern Steep Belt (18.5-14.5 Ma), with late shortening and steepening of the SFZ and a transecting relationship with regard to the Southern Steep Belt (14.5-3.0 Ma). e, f Scenario B: NW-SE cross-section of the SFZ with an initially steep geometry in the south (18.5-14.5 Ma), and late shortening and steepening of the SFZ but with a parallel relationship

folds in the Simplon area developed as the result of a similar single mechanical process (Rosenberg et al. 2007), we would expect all these folds to develop synchronously with extension, in other words from the very onset of faulting on the SFZ. In contrast, our new age results instead suggest that such upright folds more probably reflect the activity of a second independent mechanical process, with active folding occurring later in the north but still during ongoing extensional faulting.

The onset of backfolding in the Northern Steep Belt at $10 \mathrm{Ma}$ can also explain why a slight to moderate increase in the exhumation rate appears to have occurred in the external crystalline massifs and in the Lepontine area between 10 and $7 \mathrm{Ma}$ (Vernon et al. 2009; Glotzbach et al. to the Southern Steep Belt (14.5-3.0 Ma). SSB Southern Steep Belt, $P F$ Periadriatic Fault, $C F$ Centovalli Fault, SL Simplon Line, Sm2 younger ductile-to-brittle mylonitic foliation related to the SFZ, Sm older ductile mylonitic foliation related to the SFZ, $S_{1 / 2}$ pre-existent regional fabric associated to the D1-D2 deformation phase, $B$ Berisal backfold, $G$ Glishorn backfold, $V$ Vanzone backfold, $M$ Masera backfold. Active faults are in bold and the axial planes indicate the active folds

2010). Geometric models clearly demonstrate that these extension-parallel folds also enhanced the exhumation of the Toce Dome and contributed to the exhumation of the Aar culmination. It is thus to be expected that the onset of backfolding of the Northern Steep Belt should be reflected in a change in the exhumation rate.

\subsection{Evolution of the Southern Steep Belt}

The timing, kinematics and mechanics of steepening of the SFZ in the south are more difficult to establish. The Southern Steep Belt and the Vanzone antiform are considered to have developed prior to $25 \mathrm{Ma}$ (e.g. Steck and Hunziker 1994; Romer et al. 1996; Pettke et al. 1999; Steck 
et al. 2013), before the onset of the SFZ (Table 3). However, it is likely that some late perpendicular shortening overprinted this southern region as well. For example, the Masera synform shows a more open hinge geometry compared to the tight Vanzone antiform and developed under lower grade metamorphic conditions (Steck 2008; Steck et al. 2013). No direct dating constraining the age of the Masera synform is available, but it is possible that the open Masera synform resulted from late shortening and buckling of the northern, relatively flat limb of the Vanzone antiform, causing tightening both of the Vanzone antiform and of the pre-existing Southern Steep Belt (Table 3; Fig. 13), as also proposed by Steck (2008) and Steck et al. (2013).

The SFZ could either be generated as (1) a shallow normal fault crosscutting the Southern Steep Belt, later steepened during ongoing tightening (Fig. 13c, d), or (2) with an original steeper orientation in the south, parallel to the initial fabric, which subsequently underwent further shortening and steepening (Fig. 13e, f). The first solution implies a present day geometry of the Simplon Line crosscutting the southern limb of the Vanzone fold (Fig. 13d), whereas the second model implies that the Simplon Line is parallel to the foliation in the Southern Steep Belt at depth (Fig. 13f). The geometric modelling (Fig. 12c) favors initiation of the Simplon Line as a lowangle normal fault crosscutting the pre-existing Southern Steep Belt. However, this geometry results from the extrapolation of the surface field geometry to depth and there are no additional measurements (e.g. from tunnels or boreholes) that could be included to more precisely constrain this geometry at depth. Therefore, the initial geometry of the SFZ relative to the preexisting Southern Steep Belt cannot currently be solved unequivocally. In both cases, a later tightening of the whole detachment fault system to the south is likely, synchronous with amplification of the Masera synform and possibly also synchronous with the development of the Glishorn and the Berisal backfolds in the Northern Steep Zone (Table 3).

\subsection{Relationship to the previous $\mathrm{D}_{2}$ deformation phase}

The geometry of the SFZ relative to the previous fabric is also characterised by the 3D models. The Simplon Line clearly crosscuts the older $S_{1 / 2}$ fabric preserved in the hanging-wall all the way from the Rhone Valley to the Isorno Valley, with an evident 3D geometrical discontinuity at the detachment. Within the footwall, the older ductile Simplon mylonitic foliation $(\mathrm{Sm})$ and the earlier $\mathrm{S}_{2}$ foliation are parallel, reflecting reactivation and transposition of $S_{2}$ in the vicinity of the SFZ, as presented in Fig. 6. However, the two fabrics can be clearly differentiated at the limits of the study area to the northwest (region IV, Rhone Valley) and southeast (region II, Isorno Valley). In these regions, the dextral ductile shear is parallel to the brittle detachment and overprints the discordant D2 fabric. Therefore, for both structural and geometrical reasons, $S_{2}$ and $\mathrm{Sm}$ cannot be considered to be the same coeval foliation. Instead, the higher temperature mylonitic Sm foliation in the footwall of the SFZ clearly overprints the regionally developed $S_{2}$ and must be younger.

\section{Conclusions}

The Simplon low-angle detachment system in the Central Alps is affected by upright folding with axes both parallel and perpendicular to the regional extension direction. This leads to a complex 3D denudation history of the footwall and the development of a regional domal structure, the Toce Dome. Here we present new constraints on the relative and absolute timing of these upright folds coupled with a 3D geometric model of the interplay between extensional faulting and folding that led to exhumation.

The Simplon ductile mylonitic foliation forms a doubly plunging antiform with a broad domal shape. The cooling history in the footwall of the SFZ suggests that this dome formation occurred at the time of penetrative ductile shearing, between 18.5 and $14.5 \mathrm{Ma}$, which is reflected in a several kilometre wide strain gradient into the footwall. This domal shape is not recorded by the lower temperature brittle detachment, consistent with a more rigid-block exhumation below the ductile-to-brittle transition within the fault rocks. In the Northern Steep Belt, new mica ${ }^{40} \mathrm{Ar} /{ }^{39} \mathrm{Ar}$ dating suggests an onset for the development of the extension-parallel folds at ca. $10 \mathrm{Ma}$, synchronous with late movement along the SFZ, on which activity had already begun some $10 \mathrm{Ma}$ earlier. The associated orogenperpendicular shortening generates coeval wavy folds of the greenschist facies mylonitic foliation and of the brittle detachment itself. The formation of the Northern Steep Belt must have amplified the exhumation of the Toce Dome and contributed to exhumation of the Aar culmination in the late Miocene. In contrast, existing ages on crosscutting veins and dykes demonstrate that the Vanzone antiform and the Southern Steep Belt forming the southern limb of the Toce Dome must have developed before ca. $25 \mathrm{Ma}$ and therefore prior to the onset of faulting related to the SFZ. However, younger tightening of the Vanzone fold, with the development of the open Masera synform, may have subsequently steepened the SFZ in the south. We propose that the upright folds affecting this low-angle detachment system are the result of two distinct mechanical events: (1) a broad extension-perpendicular fold generated synchronously with the onset of ductile shear and reflecting a strain gradient through the shear zone, and (2) extension- 
parallel folds that were successively generated at the time of the penetrative ductile shearing and again later at the time of more localised movement along the SFZ, in both cases caused by orogen-perpendicular horizontal shortening due to continued convergence across the Alps. The finite domal shape of the Toce Dome is therefore the result of several deformational overprints that led to an exhumation pattern that can only be accurately characterised in 3D.

Acknowledgments This work was financed by the Swiss National foundation, Project Numbers: NF 200021-109187 and NF 200020-121578. The GeoModeller computer software is developed and marketed by Intrepid Geophysics and by the BRGM and is available at http://www.geomodeller.com. Thorough reviews by Marco Herwegh and an anonymous reviewer improved the final manuscript and their input is gratefully acknowledged.

\section{References}

Aug, C., Chilès, J. P., Courrioux, G., \& Lajaunie, C. (2005). 3D geological modelling and uncertainty: The potential-field method. In O. Leuangthong \& C. Deutsch (Ed.), Geostatistics Banff 2004 (Vol. 14, pp. 145-154), Springer, Netherlands.

Avigad, D., Ziv, A., \& Garfunkel, Z. (2001). Ductile and brittle shortening, extension-parallel folds and maintenance of crustal thickness in the central Aegean (Cyclades, Greece). Tectonics, 20, 277-287.

Axen, G. J., Selverstone, J., \& Wawrzyniec, T. (2001). Hightemperature embrittlement of extensional Alpine mylonite zones in the midcrustal ductile-brittle transition. Journal of Geophysical Research-Solid Earth, 106, 4337-4348.

Bartley, J. M., Fletcher, J. M., \& Glazner, A. F. (1990). Tertiary extension and contraction of lower-plate rocks in the Central Mojave metamorphic core complex, Southern California. Tectonics, 9, 521-534.

Buck, W. R. (1988). Flexural rotation of normal faults. Tectonics, 7, 959-973.

Calcagno, P., Chiles, J. P., Courrioux, G., \& Guillen, A. (2008). Geological modelling from field data and geological knowledge Part I. Modelling method coupling 3D potential-field interpolation and geological rules. Physics of the Earth and Planetary Interiors, $171,147-157$.

Campani, M., Herman, F., \& Mancktelow, N. (2010a). Two- and three-dimensional thermal modeling of a low-angle detachment: Exhumation history of the Simplon Fault Zone, central Alps. Journal of Geophysical Research-Solid Earth, 115, B10420. doi:10.1029/2009JB007036.

Campani, M., Mancktelow, N., Seward, D., Rolland, Y., Muller, W., \& Guerra, I. (2010b). Geochronological evidence for continuous exhumation through the ductile-brittle transition along a crustalscale low-angle normal fault: Simplon Fault Zone, central Alps. Tectonics, 29, TC3002. doi:10.1029/2009TC002582.

Chauvet, A., \& Séranne, M. (1994). Extension-parallel folding in the Scandinavian Caledonides: Implications for late-orogenic processes. Tectonophysics, 238, 31-54.

Drewes, H. (1959). Turtleback faults of Death-Valley, California: A reinterpretation. The Geological Society of America Bulletin, 70, $1497-1508$.

Frank, E. (1983). Alpine metamorphism of calcareous rocks along a cross-section in the Central Alps: Occurrence and breakdown of muscovite, margarite and paragonite. Schweizerische Mineralogische und Petrographische Mitteilungen, 63, 37-93.

Glotzbach, C., Reinecker, J., Danisik, M., Rahn, M., Frisch, W., \& Spiegel, C. (2010). Thermal history of the central Gotthard and Aar massifs, European Alps: Evidence for steady state, longterm exhumation. Journal of Geophysical Research-Earth Surface, 115, F03017. doi:10.1029/2009JF001304.

Grasemann, B., \& Mancktelow, N. S. (1993). Two-dimensional thermal modeling of normal faulting: The Simplon Fault Zone, Central Alps. Tectonophysics, 225, 155-165.

Grujic, D., \& Mancktelow, N. S. (1996). Structure of the northern Maggia and Lebendun nappes, Central Alps, Switzerland. Eclogae Geologicae Helvetiae, 89, 461-504.

Guidotti, C. V. (1973). Compositional variation of muscovite as a function of metamorphic grade and assemblages in metapellites from N.W. Maine. Contributions to Mineralogy and Petrology, $42,33-42$.

Haertel, M., Herwegh, M., \& Pettke, T. (2013). Titanium-in-quartz thermometry on synkinematic quartz veins in a retrograde crustal-scale normal fault zone. Tectonophysics, 608, 468-481.

Härtel, M. (2012). Strain localization in a retrograde shear zone: The Simplon Fault Zone as an example. Ph.D. dissertation, University of Bern, Bern, Switzerland.

John, B. E. (1987). Geometry and evolution of a mid-crustal extensional fault system: Chemehuevi Mountains, southeastern California. In M. P. Coward, J. F. Dewey \& P. L. Hancock (Eds.), Continental extensional tectonics. Geological Society of London Special Publication, 28, 313-335.

Keller, L. M., Hess, M., Fugenschuh, B., \& Schmid, S. M. (2005). Structural and metamorphic evolution of the CamugheraMoncucco, Antrona and Monte Rosa units southwest of the Simplon line, Western Alps. Eclogae Geologicae Helvetiae, 98, $19-49$.

Lajaunie, C., Courrioux, G., \& Manuel, L. (1997). Foliation fields and 3D cartography in geology: Principles of a method based on potential interpolation. Mathematical Geology, 29, 571-584.

Lister, G. S. (1984). Metamorphic core complexes of Cordilleran type in the Cyclades, Aegean Sea, Greece. Geology, 12, 221-225.

Mancel, P., \& Merle, O. (1987). Kinematics of the northern part of the Simplon Line (Central Alps). Tectonophysics, 135, 265-275.

Mancktelow, N. (1985). The Simplon Line: A major displacement zone in the Western Lepontine Alps. Eclogae Geologicae Helvetiae, 78, 73-96.

Mancktelow, N. (1990). The Simplon Fault Zone. Beiträge zur Geologischen Karte der Schweiz, 163, 74 pp.

Mancktelow, N. S. (1992). Neogene lateral extension during convergence in the Central Alps: Evidence from interrelated faulting and backfolding around the Simplonpass (Switzerland). Tectonophysics, 215, 295-317.

Mancktelow, N. S., \& Pavlis, T. L. (1994). Fold-fault relationships in low-angle detachment systems. Tectonics, 13, 668-685.

Martinez-Martinez, J. M., Soto, J. I., \& Balanya, J. C. (2002). Orthogonal folding of extensional detachments: Structure and origin of the Sierra Nevada elongated dome (Betics, SE Spain). Tectonics, 21, 1012. doi:10.1029/2001TC001283.

Maxelon, M. (2004). Developing a three-dimensional structural model of the Lower Lepontine nappes: Central Alps, Switzerland and Northern Italy. Ph.D. dissertation, ETH-Zürich, Zürich, Switzerland.

Maxelon, M., \& Mancktelow, N. S. (2005). Three-dimensional geometry and tectonostratigraphy of the Pennine zone, Central Alps, Switzerland and Northern Italy. Earth-Science Reviews, 71, 171-227.

Maxelon, M., Renard, P., Courrioux, G., Braendli, M., \& Mancktelow, N. (2009). A workflow to facilitate three-dimensional 
geometrical modelling of complex poly-deformed geological units. Computers \& Geosciences, 35, 644-658.

Michalski, I., \& Soom, M. A. (1990). The Alpine thermo-tectonic evolution of the Aar and Gotthard massifs, Central Switzerland: fission track ages on zircon and apatite and K-Ar mica ages. Schweizerische Mineralogische und Petrographische Mitteilungen, 70, 373-387.

Milnes, A. G. (1974). Structure of Pennine zone (Central Alps): A new working hypothesis. The Geological Society of America Bulletin, 85, 1727-1732.

Milnes, A. G., Greller, M., \& Müller, R. (1981). Sequence and style of major post-nappe structures, Simplon-Pennine Alps. Journal of Structural Geology, 3, 411-420.

Pettke, T., Diamond, L. W., \& Villa, I. M. (1999). Mesothermal gold veins and metamorphic devolatilization in the northwestern Alps: The temporal link. Geology, 27, 641-644.

Pleuger, J., Mancktelow, N., Zwingmann, H., \& Manser, M. (2012). $\mathrm{K}$-Ar dating of synkinematic clay gouges from Neoalpine faults of the Central, Western and Eastern Alps. Tectonophysics, 550, $1-16$.

Preiswerk, H. (1921). Die zwei Deckenkulminationen Tosa-Tessin und die Tessiner Querfalte. Eclogae Geologicae Helvetiae, 16, 485-496.

Romer, R. L., Scharer, U., \& Steck, A. (1996). Alpine and pre-Alpine magmatism in the root-zone of the western central Alps. Contributions to Mineralogy and Petrology, 123, 138-158.

Rosenberg, C. L., Brun, J. P., Cagnard, F., \& Gapais, D. (2007). Oblique indentation in the Eastern Alps: Insights from laboratory experiments. Tectonics, 26, TC2003. doi:10.1029/2006 TC001960.

Spencer, J. E. (1984). Role of tectonic denudation in warping and uplift of low-angle normal faults. Geology, 12, 95-98.

Spencer, J. E. (1985). Miocene low-angle normal faulting and dike emplacement, Homer Mountain and surrounding areas, southeastern California and southernmost Nevada. The Geological Society of America Bulletin, 96, 1140-1155.

Spencer, J. E. (2010). Structural analysis of three extensional detachment faults with data from the 2000 Space-Shuttle Radar Topography Mission. The Geological Society of America today, 20, 4-10.

Steck, A. (1984). Structures de déformations Tertiaires dans les Alpes centrales. Eclogae Geologicae Helvetiae, 77, 55-100.

Steck, A. (1990). Une carte des zones de cisaillement ductile des Alpes Centrales. Eclogae Geologicae Helvetiae, 83, 603-627.

Steck, A. (1998). The Maggia cross-fold: An enigmatic structure of the lower Penninic nappes of the Lepontine Alps. Eclogae Geologicae Helvetiae, 91, 333-343.
Steck, A. (2008). Tectonics of the Simplon massif and Lepontine gneiss dome: deformation structures due to collision between the underthrusting European plate and the Adriatic indenter. Swiss Journal of Geosciences, 101, 515-546.

Steck, A., Della Torre, F., Keller, F., Pfeifer, H.-R., Hunziker, J., \& Masson, H. (2013). Tectonics of the Lepontine Alps: Ductile thrusting and folding in the deepest tectonics levels of the Central Alps. Swiss Journal of Geosciences, 106, 427-450.

Steck, A., \& Hunziker, J. (1994). The Tertiary structural and thermal evolution of the Central Alps-Compressional and extensional structures in an orogenic belt. Tectonophysics, 238, 229-254.

Steiger, R. H., \& Jäger, E. (1977). Subcommission on geochronology: Convention on use of decay constants in geochronology and cosmochronology. Earth and Planetary Science Letters, 36, 359-362.

Vance, D., \& O’Nions, R. K. (1992). Prograde and retrograde thermal histories from the Central Swiss Alps. Earth and Planetary Science Letters, 114, 113-129.

Vernon, A. J., van der Beek, P. A., Sinclair, H. D., Persano, C., Foeken, J., \& Stuart, F. M. (2009). Variable late Neogene exhumation of the central European Alps: Low-temperature thermochronology from the Aar Massif, Switzerland, and the Lepontine Dome, Italy. Tectonics, 28, TC5004. doi:10.1029/ $2008 \mathrm{TC} 002387$.

Wawrzyniec, T., Selverstone, J., \& Axen, G. J. (1999). Correlations between fluid composition and deep-seated structural style in the footwall of the Simplon low-angle normal fault, Switzerland. Geology, 27, 715-718.

Wawrzyniec, T. F., Selverstone, J., \& Axen, G. J. (2001). Styles of footwall uplift along the Simplon and Brenner normal fault systems, Central and Eastern Alps. Tectonics, 20, 748-770.

Wenk, E. (1955). Eine Strukturkarte der Tessineralpen. Schweizerische Mineralogische und Petrographische Mitteilungen, 35, 311-319.

Wernicke, B. (1981). Low-angle normal faults in the Basin and Range Province: Nappe tectonics in an extending orogen. Nature, 291, 645-648.

Wernicke, B., \& Axen, G. J. (1988). On the role of isostasy in the evolution of normal-fault systems. Geology, 16, 848-851.

Yin, A. (1991). Mechanisms for the formation of domal and basinal detachment faults: A 3-dimensional analysis. Journal of Geophysical Research-Solid Earth and Planets, 96, 14577-14594.

Zwingmann, H., \& Mancktelow, N. (2004). Timing of Alpine fault gouges. Earth and Planetary Science Letters, 223, 415-425. 